\title{
A systematic literature review on the service supply chain: research agenda and future research directions
}

\begin{abstract}
This paper provides a methodological overview of service supply chain research through a comprehensive review of published literature, enabling us to describe the service supply chain from a knowledge perspective. The nature of the service supply chain is substantially different from the characteristics of the traditional supply chain. Consequently, the robustness of ideas underpinning this area of research has not been fully analysed by the academic community and a more cross-disciplinary approach is needed. Following comprehensive review, all the selected papers can be divided into nine generic groups in terms of problem focus in the service supply chain. These were production processes, human resources, logistics, information technology, theory and model generation, productivity and profitability, environmentally friendly practices, customer satisfaction and other cross-disciplinary studies. Four key aspects of the service supply chain are recommended for future research, namely: environment-friendly practices, market relationships, information technology integration and adoption of industryspecific case studies. In future extensions, additional work can include and correlate knowledge from other disciplines, theoretical perspectives, intellectual trends, and traditional practices associated with service industries. Lastly, this study could be used as a starting point for establishing a future research agenda in the area of the service supply chain.
\end{abstract}

Keywords: supply chain management; design for service, service supply chain; systematic review, service industries.

\section{Introduction}

Before the 1980s, separate organisations were responsible for ensuring excellence in product development, operations, logistics, maintaining quality standards and marketing. Due to the quality revolution of the early 1980s, supply chain management was introduced to sustain fierce competition among companies (Oliver and Webber 1982). Over the years, a growing number of companies have realized the importance of integrating management with ongoing process rather than managing them separately and thus have introduced supply chain management as a discipline in management (La Londe 1997). As pointed out by Melo, Nickel, and Saldanha-Da-Gama (2009), Supply chain management is "the process of planning, implementing and controlling the operation in an efficient way".

So far, management literature has largely examined manufacturing supply chains (Beamon 1999). Like the manufacturing sector, service organisations also play an important role in the global economy, contributing $30.4 \%$ to $87.2 \%$ to gross domestic productivity (GDP) across 
countries of both industrialized and emerging economies, as listed on the World Bank website in 2017. However, to date, there has been little comprehensive analysis of the literature on the 'service supply chain' (Ellram, Tate, and Billington 2004; Ellram and Cooper 2014). Given the rapid economic expansion of service activities of global businesses in recent times (Kowalkowski et al. 2015), the service supply chain has become an important topic for debate amongst the key researchers in the operations management area (Wang et al. 2015; Chithambaranathan et al. 2015; Aitken et al. 2015; Holmström and Partanen 2014). However, there is still lack of fundamental research in this area, meaning our understanding of the topic is still rudimentary (Baltacioglu et al. 2007; Boon-itt, Wong, and Wong 2017; Harvey 2016) which is limiting its advancement in terms of quality, process excellence and integration.

Previously, service sector research received less attention because most economies relied largely on advancing industrial and agriculture industries (Robinson and Malhotra 2005; Du et al. 2016; Borodin et al. 2016; Liao, Hu, and Ding 2017). Another reason for its lesser appeal for research was because of the common misconception of directly applying best practice manufacturing supply chain management tools in the service sector to get better outcomes (Ellram, Tate, and Billington 2004). Previous studies mostly focused on the manufacturing and transportation sectors (Baltacioglu et al. 2007; Masali 2016; AL-Shboul 2017; Zhu and Tian 2016; He et al. 2016) but the emergence of the recent boundary less business world has changed this perception. The success of the service sector in US is directed attributed to robust second half economic performance (valued by GDP) to the world's principal economy in 2014 (Guardian 2015). Correspondingly, the major share of GDP of other advanced countries are predominantly due to service industries (Economist Intelligence Unit 2013). The World Development Indicators in 2011 established that the service sector accounted for $71 \%$ of total world GDP with a faster growing pace than its manufacturing counterpart ( $\mathrm{Ru}$ et al. 2012; Rezapour, Allen, and Mistree 2016; Masteika and Čepinskis 2015). Exports in the service industry grew by $11 \%$ from 1980 to 2011, an even higher rate than merchandise, and now accounts for US $\$ 4.1$ trillion. Developing countries generated $29.82 \%$ of this value and $2.85 \%$ was from transition economies (World Bank 2016). This development and the inherent difference between manufacturing and service sectors (Ellram, Tate, and Billington 2004; Ellram and Cooper 2014; Scheibe and Blackhurst 2017) justifies new efforts to unpack the challenges and barriers related to the service supply industries (Boon-itt, Wong, and Wong 2017) and find the best supply chain management practices for service organizations. Considering its future potential, only a few studies have tried to integrate service activities in a supply chain framework to increase the intrinsic value of firms (Field and Meile 2008; Sampson and Froehle 2006; Sengupta, Heiser, and Cook 2006; Reimann and Ketchen 2017; Hussain, Khan, and Al-Aomar 2016).

Taking these considerations into account, this paper will review previous scholarly works in the field of service supply chain, to assess the maturity of the discipline and to create a possible agenda for future researchers. To this end, this study primarily reviews existing literature that may be even partially relevant to the way the service supply chain has been conceptualized and applied. In particular, in Section 2, the origin and concept of the service supply chain is provided. The next section illustrates the methodology that was followed in conducting this 
systematic review. Section 3 presents the scope of the present study from six major dimensions. The strategy used to search and identify associated papers that were consistent with the service supply chain is described in Section 4. The related literature is then categorized in Section 5. Finally, the paper concludes with an assessment of the current advancement of the service supply chain literature and highlights the significant research gaps to be further investigated by future researchers and practitioners.

\section{The conceptualization of supply chain with service elements integration}

\subsection{The supply chain and supply chain management}

Supply chain management, as a formal research topic, is still considered a new area of management research. The notion of supply chain activities has a long relationship with business ( $\mathrm{Li}$ et al. 2014; Jie and Gengatharen; Thai, Jie, and Logistics 2018). Previous researchers have worked towards analysing the industrial or production chain rather than service supply or service logistics chain management (Seuring and Müller 2008; Croom, Romano, and Giannakis 2000; Burgess, Singh, and Koroglu 2006; Feng, Zhu, and Lai 2017; Stephens, White, and Mason-Jones 2016; Stank et al. 2015; Schaltegger and Burritt 2014). This scenario is rapidly changing as upcoming studies are more diversely interested in traditional supply chain research topics (Yawar and Seuring 2017; Dubey et al. 2017; Liu et al. 2015; Jin and Yang 2016; Fredendall, Letmathe, and Uebe-Emden 2016; Sajjad, Eweje, and Tappin 2015; Touboulic and Walker 2016; Brandenburg et al. 2014; Winter and Knemeyer 2013).

The definition of the supply chain has been immensely influenced by the authors' points of view, but is largely concentrated on building an extended relationship between suppliers, organizations and customers, as shown in Figure 1 (Mentzer et al. 2001). Based on this idea, Mentzer et al. (2001) classified the supply chain into three types: direct supply chain (Figure 1a), extended supply chain (Figure 1b) and ultimate supply chain (Figure 1c). A direct supply chain is conceptualised by keeping manufacturing organization in middle as intermediary between suppliers and customers.

$<<$ Include figure $1>>$

The supply chain can be defined as a set of three or more entities (organizations or firms) directly involved in the upstream and downstream flow of products, services, finances, and/or information from a source to a customer (Mentzer et al. 2001). Other authors in the field come to the same conclusion in their published works (Anklesaria 2008; Chopra and Meindl 2007; Hugos 2003; Shapiro 2001; Kurata and Nam 2013; Carter, Rogers, and Choi 2015).

In terms of defining supply chain management, authors definitions varied based on the author's understanding and contextual viewpoint (Mentzer et al. 2001; Asgari et al. 2016; Ellram and Cooper 2014). In the beginning, the supply chain management concept originated from the value chain insurgence (Dale et al., 1994), philosophies of material control and unified logistics (Carter and Price 1993; Forrester 1961), manufacturing linkages (Ford 1990; Jarillo 1993), improved motivation (Porter 1987; Snow, Miles, and Coleman 1992) and productiveness 
(Lamming 1993; Womack, Jones, and Roos 1990). Table 1 highlights the valuable contributions towards the notion of the supply or value chain management. Past scholars have also framed the topic to describe inter organizational concerns (Harland, Lamming, and Cousins 1999), upright amalgamation (Snehota and Hakansson 1995; Thorelli 1986), supplier connections (Hines 1994; Narus and Anderson 1995; Saban, Mawhinney, and Drake 2017), and procurement related issues (Farmer 1997).

\section{$<<$ Include table 1>>}

\subsection{The integration of service elements with supply chain management}

Past authors have found it particularly difficult the field of service supply chain given its nature and coverage of the business activities (Tseng et al. 2018). Analogous to manufacturing supply chain - services supply chain involves several broad entities such as service providers, suppliers of sub-services or resources needed for the design and delivery of services, and service clients or customers - all working together to co-produce value in diverse value chains or networks (Giannakis 2011a). Historically, majority of operation management research was focused on the manufacturing/production processes, but recent trends show a change as there are new studies emerging on service operations management (Kathawala and Abdou 2003; Liu, Ge, et al. 2014; Liu, Liu, et al. 2014; Li et al. 2016). Defining the service supply chain is not an easy task, as it involves multiple actors/entities in the service creation and delivery phases when compared to the production supply chain (Spohrer et al. 2007; Sigala 2014; Liu et al. 2012). One of the pertinent question in case of service supply chain is the scope of the conceptual model developed - broad or narrow view. Some of the previous definitions are presented in Table 2.

\section{<<Include table 2〉>}

Service suppliers, often characterized as a focal firm, pull resources from diverse subcontractors and assimilate these resources into the creation of a "core service" which is distributed to the end customer (Baltacioglu et al. 2007; Liu, Bai, et al. 2017; Tseng et al. 2016). In 2006, Sampson and Froehle looked at the service supply chain to create a unified model for all the service activities in a broad view. They pointed out the differences, especially the bidirectional nature of the service supply chain. Their qualitative research pointed out that service supply chain tends to be the hub rather than the chain and were smaller in size which eventually narrowed down the definition of service supply chain. It was also suggested that the service supply chain also needed to be robust enough to handle random order arrivals, inconsistent specifications and varying input quality. Similar suggestions were made by other researchers as well (Lovelock 1983; Sampson 2000; Stuart 1997; Bustinza, Parry, and Vendrell-Herrero 2013; Johnsen, Miemczyk, and Howard 2017; Lay et al. 2010). In 2011, Lillrank and Sarkka reviewed the existing theoretical literature on outsourcing, operations management, contracting, and governance to explore a new conceptual model for governing outsourcing arrangements, using an inbound voice call centre as an example. Their supply chain also inherited double directional input flows given consumers also supply inputs. Another reason behind the scarcity of service supply chain models may be attributed to the traditional 
focus on the more widely accepted models, an obstacle to the development of service supply chain literature (Nie and Kellogg 1999). Roth and Menor (2003) proposed another methodology where their approach was to create an agenda for service operations management research. They placed importance on expanding service operation boundaries and customer experience. In recent time, $\mathrm{Li}$, Jiang, and Liu (2012) considered interaction between two service suppliers each with a distinct line as an standard of service supply chain. Clienteles joined one queue upon entrance and can change in real time amid lines to exploit their spot utility that is a purpose of queue length and price within the system.

Given the past scholarly works, several issues can be identified to shape the service supply chain research agenda in future. The managerial implications of the past research frameworks need to be comprehensively assessed and structured to make them more understandable to common practitioners. Thus, a systemic literature review of service supply chain operations would be of great scholarly interest to practitioners and researchers in this field.

\section{Research methodology}

Conceptual literature analysis is an integral part of any management research (Baker 2000; Cooper 1988) and is used to gather knowledge (from past academics) to develop a coherent and clear understanding of a particular research topic to identify literature gaps and provide new research directions (Rowley and Slack 2004; Tranfield, Denyer, and Smart 2003). Our research methodology built on similar concepts of analysing current accessible literature on the service supply chain in a systematic manner. Throughout this systematic literature review process, we used several criterion to select and analyse scholarly works in a highly transparent and replicable manner (Vom Brocke et al. 2009).

In the last few decades, different systematic literature review processes have been introduced (Colicchia and Strozzi 2012; David and Han 2004; Newbert 2007; Seuring and Gold 2012; Habib, Bastl, and Pilbeam 2015). Unfortunately, most of them have a common disadvantage: their core focus is only on the analysis and synthesis (Fischl, Scherrer-Rathje, and Friedli 2014). This paper overcomes this limitation by employing a modified model created by vom Brocke et al. (2009) to process the literature with a broader view. Some of the steps involved in this process are:

1. Conceptualization and origin of the key terminologies

2. Defining the review scope

3. Systematic literature search

4. Literature analysis and synthesis

5. Findings and managerial implications

As per the abovementioned steps, the conceptualisation and origins of key terms used in the service supply chain have been detailed in Section 2 and current thoughts that provide focus and context to this research field are organised. A broad definition of the key terminologies used in the service supply chain field is given with the help of textbooks, journal papers and 
handbooks consistent with good practices of the systematic literature review (Zorn and Campbell 2006; Baker 2000). The following section provides details on defining the review scope in this paper.

\section{Defining the review scope}

In this section, the literature review scope is defined based on the Cooper's (1988) taxonomy of six dimensions: focus, goals, organisation, perspective, audience and coverage. Table 3 shows the review scope used while conducting the current literature review.

\section{$<<$ Include table 3>>}

Each of the six dimensions are explained as follows:

i. Focus: the focus of any research can be defined typically by the emphasis of the researchers' intention through research outcomes, methods, theories and applications analysis (Bem 1995; Torraco 2005). In this systematic review of service supply chain research, outcomes or theories can be defined as the key focus of the paper, given that the amount of past research in this context is very limited and at the same time a common understanding is very much required. Thus, this paper will focus on creating a new understandable theory of service supply chain through research outcomes.

ii. Goal: The goal of a literature review may be an amalgamation or production of past literature, a critical analysis of existing literature, or the identification of issues central to a field (Cooper 1988). This paper concentrates on integrating the works of past research on this field to create a new framework for future knowledge.

iii. Organization: Cooper (1988) recommends a historical, conceptual and/or methodological structure to organize a research paper. In this paper, conceptual structure is used rather than historical or methodological structure, given the goal of the paper is based on outcome and theories. Also, conceptual organization works well with past literature integration.

iv. Perspective: Perspective is the personal viewpoint or predetermined understanding of a topic (Crotty 1998). In this review paper, the natural perspective has been used to understand the position from a simple point of the spectators.

v. Audience: The audience are the readers or knowledge gathers of the research outcomes and have the unique ability to influence the writing and presenting style of the researchers (Bem 1995). Given the scarcity and future impact of the scholarly work, the main audience of this paper will be researchers and practitioners working in service supply chains.

vi. Coverage: Coverage can be defined as the base of a review scope. Given the modern high pace research environment, this paper focuses the sample selection for this literature analysis work to be representative of the size and presence of service industries. 


\section{Systematic literature search}

A systematic literature search process is key to any proper literature review. A literature search encompasses the querying of scholarly databases using keywords and retrograde searches to source relevant articles (Webster and Watson 2002). As per the work of vom Brocke et al. (2009), this paper uses a non-repetitive strategy to search through the current databases, as described below:

i. Journal Selection: Modern day literature searches primarily rely on journal databases. To maintain a level of research quality within a range of fields, academics need to look to the literary works of fellow researchers in the form of journals and conference proceedings (Rowley and Slack 2004). This paper used peer reviewed journals rather than conference proceedings. The search process was performed in a highly controlled manner and was further refined by the high publication standards of journals (Flick 2008). This paper used "The International Guide to Academic Journal Quality" - by the Academy of Business School and Australian Business Dean's Council ranking to address the quality issue and select the best journals. Apart for this, around ten percent of additional journal papers were also selected due to their high citation records.

ii. Database selection: A number of databases are available for management researchers. Given the content of this paper, we used the four most distinguished research paper databases: EBSCOhost, Emerald, ProQuest and Science Direct.

iii. Keyword search in database: A set of keywords synonymous to the objective of the search was used in the process. As given in Table 4, four sets and twelve subsets of keywords or phrases were searched within the four databases. From the results, we picked the journal articles which we found the most suitable for our research objective. After deducting the duplications, the keyword search phase generated 79 articles relevant to this literature review.

$$
<<\text { Include table 4>> }
$$

iv. Backward and forward searches: In the last step of the journal search, a forwardbackward search procedure was initiated. Past researchers have argued that occasionally, for unavoidable reasons, important journals can be overlooked (Zhou and Ye 1988). A forward-backward search through the timeline ensures that these journals are picked up for analysis. Figure 5 represents the journals collected through the forward-backward timeline analysis and our result revealed the same result (in terms of resulting set of papers identified for review) after removing duplicates. 


\section{Analysis and Synthesis of selected literature}

In order to conduct a transparent representative synthesis of the 79 collected papers, a contentbased analysis was undertaken. A list of the journals where the papers are from is attached at table 6.

\section{$<<$ Include table 5>>}

The initial analyses revealed that the papers were highly dominated by case analysis and empirical studies: $86 \%$ separated equally (Figure 3). Editorial was only 1\%, literature reviews focussed on "the characteristics of the service system supply chain" covered the rest. An empirical study was the preferred method for the researchers to find a definitive answer for a particular research question of this field. On the other hand, case study was the second most preferred method to investigate problems in the service supply chain within a particular case.

$$
\begin{aligned}
& <\text { Include figure } 3>> \\
& <<\text { Include figure } 4>>
\end{aligned}
$$

However, a further in-depth analysis of the contents of the 79 papers revealed that despite being published in different journals, there were nine generic groups (in terms of problem focus in the service supply chain): production processes, human resources, logistics, information technology, theory and model generation, productivity and profitability, environmentally friendly practices, customer satisfaction and cross-disciplinary studies (Figure 3 and 4).

i. Production process: Like the general supply chain, articles related to production processes dominated this field with nearly $27 \%$ (18 articles) related to production/service creation processes. This is consistent with the findings of other researchers of this field (Fischl, Scherrer-Rathje, and Friedli 2014). Table 5 contains a brief description of the findings of previous scholars. From the analysis, it can be observed that given the complexity of the service organizations, past researchers mostly used country-based case studies to understand the challenges related to the service supply chain (Haszlinna Mustaffa and Potter 2009; Rahimnia and Moghadasian 2010). Their preferred sector of investigation was predominantly the health service give its generic supply chain nature (De Vries and Huijsman 2011; Lillrank, Groop, and Venesmaa 2011). The key research interest in most of these papers was service supply chain integration (Braziotis et al. 2013). However, their approach varied from case to case (Saccani, Johansson, and Perona 2007), as per the needs of the service supply chain industry, as they commonly focussed on operational or strategic integration (He and Lai 2012). For example, service outsourcing in manufacturers' supply channel strategies (Bian, Lai, and Hua 2017), organizational design change in multinational supply chains (Roh et al. 2017), and global quality of the service level (Zhang et al. 2017). A key concern was the servitization movement (Braziotis et al. 2013; Alghisi, Saccani, and Control 2015). Past researcher were particularly interested on the question of after sales service (Guajardo, Cohen, and Management 2018; Murali et al. 2016; Sun 
et al. 2018). In one hand, in can be argued that they are part of a larger supply chain on the other hand they could be a separate service supply chain also given the nature and operation of the system. A detailed record of past researchers' findings can be found in Table 5.

ii. Productivity and profitability: Output and cost-effectiveness related studies were the second largest group representing $18 \%$ of the literature in this field mostly focusing on process simplification. These studies mostly employed different financial tools to measure performance and standards through which they tried to estimate the industry competitiveness in the case of service supply chains (Table 5). By doing so, they effectively created different generic models for service industries to be used to maximize production and financial efficiency (Durugbo and Riedel 2013; Fu et al. 2013; Martin et al. 2017). These models emphasised structured operational planning (de Leeuw and Wiers 2015; Selviaridis and Norrman 2014) or computer operated automated systems (Fairchild 2005; Vickery et al. 2003). They also highlighted the different performance improvement techniques through reducing backlog (Anderson and Morrice 2000) or high workloads (Akkermans and Vos 2003). These studies attempted to deliver direction for stakeholders who wanted to oversee a business process and administrators who wanted to uninterruptedly progress an existing system (Cao and Jiang 2013). They found that each party could be beneficial in using bidirectional options contracts (Chen, Wan, and Wang 2017) or when sensitivity was low (Yu and Xiao 2017). Another study established that demand uncertainty and service requirements affected buyers' optimal ordering policies (Hu and Feng 2017).

iii. Theories and model generation: The service supply chain has been regarded as one of the most prominent and upcoming research topics in the managerial and operations management area. Current established theories and models for this sector are scarce compared to other operations management areas. This systematic literature analysis revealed only eight articles (10\% of the total) discussed service supply chain theories and models. Most of these studies discussed the basic framework of the service supply chain using explanatory models. Only one paper performed a systematic literature review on environmentally sustainable or green logistics practices involved in the service supply chain (Rossi et al. 2013). Another paper looked into the strengths and weaknesses of past research (Burke et al. 2004) and how to use it to deal with the upcoming challenges and opportunities of the field (Youngdahl, Ramaswamy, and Verma 2008; Choudhury and Daly 2019). In 2000, Youngdahl and Loomba extended the service supply chain to a global context which opened debate on service supply chain theories. Where some authors used or prescribed generic models (Giannakis, M., 2011), others prescribed case-by-case based solutions for the service sector ( $\mathrm{Zu}$ and Kaynak 2012).

$<<$ Include table 6>> 
iv. Information technology: Past researchers put great emphasis on the use of information technology for the advancement of the service supply chain. One of the core pillars of the service supply chain was identified as technological assistance. The systematic analysis identified eight papers, or $13 \%$, related to the use of information technology in the service supply chain field. There is still a lot of scope for future research in this field (Venkatesh 2013). The findings of these papers pointed out the lack of consistency and the need for quality data to further progress research in this field (Bhakoo and Chan 2011). The use of hybrid solutions for the flow of goods and services could be very helpful for this purpose (Holmström and Partanen 2014; Véronneau and Roy 2009). But overall, their conclusions were positive about customer satisfaction on the issue of increased technological use in the service supply chain (Croom and Johnston 2003; Zsidisin, Jun, and Adams 2000). Recently, with the development of online shopping, manufacturers have extended their traditional retail channel and adjusted pricing and servicing decisions to enhance customer satisfaction (Wang, Song, and Wang 2017).

v. Logistics: In the service supply chain, logistics have been given lesser attention than other sub-sectors of this field. This may be due to the lack of physical product movement in service management. Eight papers (10\% of the total) were identified as seminal research publications in the logistics sub-field. Most of the academics were interested in optimal quality for the logistics system, based on the integration of service components (Piplani and Saraswat 2012). Increasingly, improving the quality of logistics operations resulted in increased cost of logistics operations (Wei-hua et al. 2011). Reducing logistics costs resulted in a decrease in customer satisfaction. Thus, logistics operations should incorporate a system approach with strategic orientation (Aronsson, Abrahamsson, and Spens 2011). The increase in logistics service quality could lead to greater customer demands with positive elasticity (Liu and Xie 2013), and eventually may create healthier relationships with consumers (Li et al. 2012), and enhanced financial return on investments (Qin, Su, and Huang 2017). More recent publication has identifies logistics as one of the most contemporary issue in service supply chain ( $\mathrm{Li}$ and Society 2014).

vi. Human resource related: Only four papers focussed on human resources. Authors looked into the service contracts for the supply chain and at how those contracts influenced service supply chain coordination (Sieke, Seifert, and Thonemann 2012). Another study focused on job satisfaction and industrial commitments across different workforce levels (Maloni et al. 2017). The remaining two studies found that collaborative decision-making could improve the workforce satisfaction level and operational performance in the service supply chain (Mandal and Jha 2017; Nematollahi, Hosseini-Motlagh, and Heydari 2017).

vii. Environment friendly practices: The "green" supply chain is one of the most recent research issues in supply chain management. The same initiative to incorporate environment friendly practices can be found in the service supply chain. In the systematic literature review, four papers were related to this issue. Most of the authors 
looked mostly at energy efficiency and performance in service delivery management (Genovese, Koh, and Acquaye 2013; Saha et al. 2019) and proposed models to retrofit the service supply chain (Chithambaranathan et al. 2015). Zhang, Joglekar, and Verma (2014) proposed using eco-certificates to boost the green management of service supply chains. As such, the service providers (with eco-certificates) achieved higher profit than their non-conforming counterparts.

viii. Customer satisfaction: Five papers were identified that related to customer satisfaction. These papers mostly focused on the relationship between marketing and service operations. In doing so, they looked at issues such as marketing mix for the service supply chain (Keller et al. 2006); a marketing operations interface (Kurata and Nam 2010), managerial implications of different marketing decisions (Sampson 2000), service quality coordination (Qin et al. 2017) and dual buy-back contract decisions (Heydari, Choi, and Radkhah 2017).

ix. Others: About $6 \%$ of the selected articles were cross-disciplinary in nature. They looked at issues like using the Nash equilibrium (Liu and Wang 2015; Liu, Xie, and Xu 2013) and the contingency theory (Yuen et al. 2017) to enhance service supply chain performance, and different scopes of scheduling effects on service supply chain (Brunner and Bard 2013; Wren et al. 2003; Chai, Liu, and Ngai 2013) .

\section{Future research agenda, new conceptual framework and conclusion}

In this paper, a comprehensive and systematic review of literature in the field of service supply chain was conducted. This study enabled us to concisely describe the service supply chain from a knowledge perspective and to define a future research agenda.

The systematic literature review was conducted based on the principles of (Vom Brocke et al. 2009). Based on the analysis and synthesis in Section 6 and Table 5, it can be suggested that the service supply chain methodology is still at a preliminary stage but with increasing interest from researchers and practitioners. The majority of service supply chain research has been focused on the more traditional concepts of supply chain management. The nature of the service supply chain is different from the characteristics of the traditional supply chain system. Consequently, the robustness of ideas underpinning this area has not been fully investigated by the academic community. If the present trend continues, there is a high risk of knowledge narrowing down in the area of the service supply chain. Thus, a more cross disciplinary approach is required to understand and develop this research area. Issues such as logistics, production processes and productivity are well discussed in the literature, therefore, future investigations should focus on environmentally friendly practices, better market orientation and service provider-customer relations. Dealing with these contemporary issues will also explore new ways to improve service operations and increase productivity and profitability. The use of superior technological infrastructure and modes are relatively a well understood practice in a productive supply chain (Puspitasari and Jie 2018). Thus, more research efforts 
should be devoted to incorporating these technological advancements in the service sector. From the synthesis recorded in Section 6, it can be clearly seen that the service supply chain differs from industry to industry so future research should be industry specific. Figure 5 incorporates these recommendations for future researchers and shows that, given the needs and requirements of practitioners, future service supply chain research should focus on four segments: environmentally friendly practices, market relationships, information technology infrastructure development and industry specific study.

$<<$ Include figure 5>>

This study provides useful insight into the service supply chain research. One possible direction of research could be to study the future framework presented in this paper. This could be in the form of the cross-tabulation data and/or content analysis presented in this study. Another way of extending this work would be to include and correlate knowledge from other disciplines, theoretical perspectives, intellectual trends, and traditional practices associated with service industries. These future inquiries will help researchers to test and relate the findings of this paper to better judge the different claims made in the service supply chain discipline.

Finally, the topic of the service supply chain offers a variety of interconnected cross disciplinary research opportunities. Past researchers emphasised the delegation of resources in accordance with the need of the services. Based on the service requirements and demands of the customer, the service supply chain can change dramatically. Hence, the body of knowledge of the service supply chain discipline needs to assist service industries to decide if current managerial strategies are good enough to support ongoing investment or if they are simply the result of short-lived enthusiasm, and should cease to support scarce resources that could be used more effectively. In this regard, we have synthesized a new conceptual framework for the current service supply chain operations in figure 6 . We have divided the process environment into four main parts- core process, external factors, internal factors and satisfaction feedback. The core process is further structured into three activities - service vendor, service delivery and end user where the service provider is continuously influenced by the external factors, internal factors and the customer satisfaction feedback (Liu, Zhao, et al. 2017a; Yang et al. 2018). We believe the interaction between this conceptual framework can easily describe any modern service operation function-ability.

We have investigated the coverage and objectives of the service supply chain research from a contextual narrative. It should be noted that service supply chain can cover a number of aspects relevant to various interdisciplinary contextualisation. As per our synthesis of the past literature, we have divided the research views on service supply chains into three generalised segments based on their coverage/scope and aim/objectives (see Fig. 7).

The service supply chain research can be classified into three major views - narrow, broad, and global view (see Fig. 7). The research involving narrow view of service supply chains are focussed on the process-specific and/or internal organisational considerations in terms of their 
scope. The major objective of studies falling under this category aimed at maximising profits, validation of process models, and evaluation of process performances. In case of broader view, the scope for the research studies expanded to include multiple organisational partners working together to provide services. Typical research studies in this category involved supplierproducer relationship and collaborations among supply chain partners. The aim of these studies were to gain system wide efficiencies and prioritisation of processes for improved service delivery. Finally, global view of service supply chain deals with the development of theories taking into account discipline specific global context and/or multi- disciplinarities. Research studies falling under this category aimed at innovating processes, building theories to better understand service delivery in the global context.

It can be also noted that - with the increasing scope of research studies in service supply chain area; the aims of research studies varied from process-specific emphasis through to long-term process innovation, macro quality management as well as development of theoretical models. Given the complexity of service supply chains, a more border view of service supply chain in current business environment taking into account global perspectives will be of utmost importance.

Finally, we suggest that future researchers should understand the internal mechanisms of any service supply chain and produce case or industry-based research agendas taking into account global views. We hope that future researchers, academics, and practitioners will use these findings to further develop their understanding on the service supply chain but more importantly, supply chain academics could consider this study as a starting point to set their future research agenda in this area.

$<<$ Include figure 6>>

$<<$ Include figure 7>> 


\section{List of Figures and Tables}

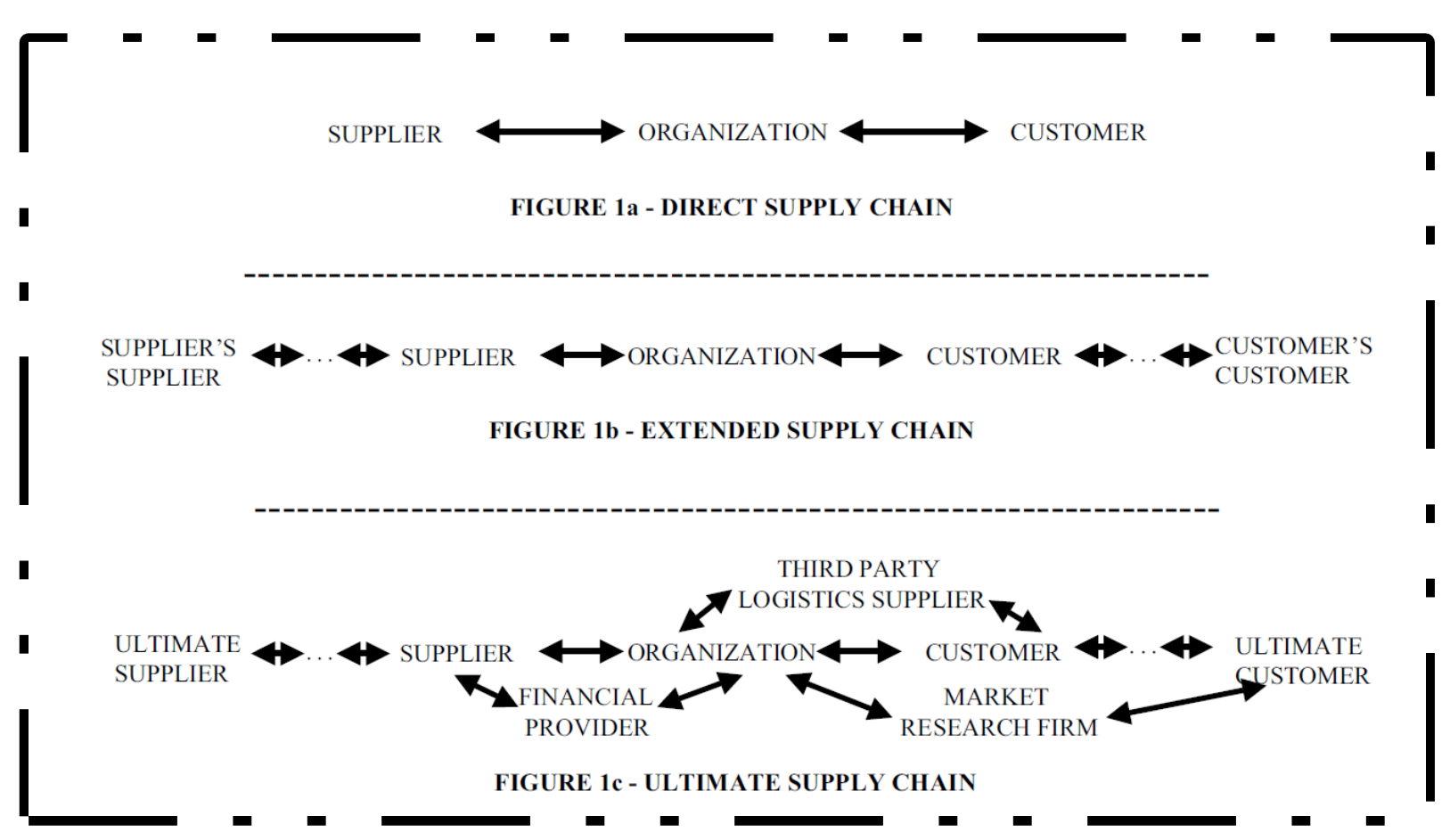

Figure 1 Supply chain model by Mentzer et al. 2001

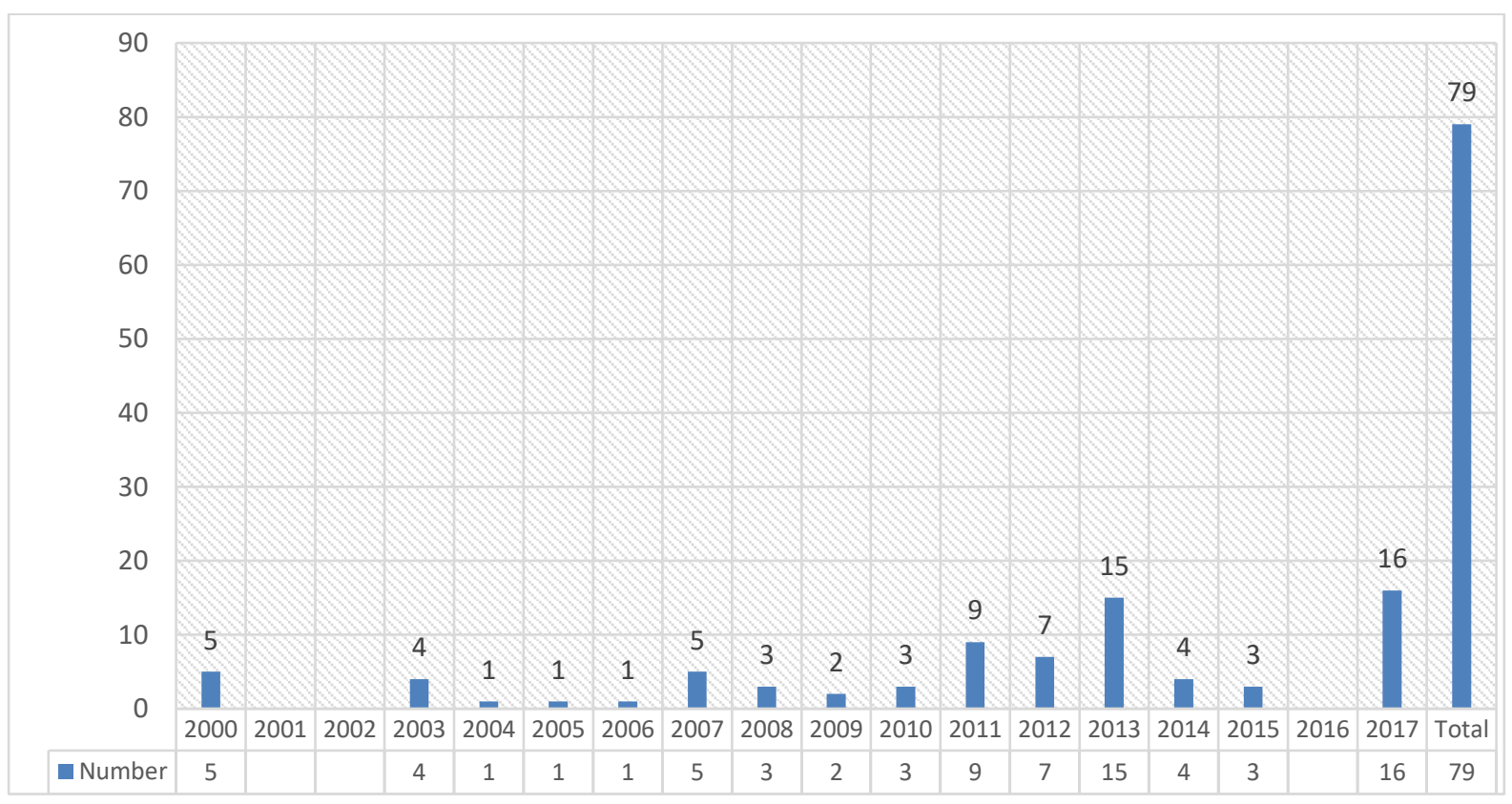

Figure 2 Backward and forward search result 


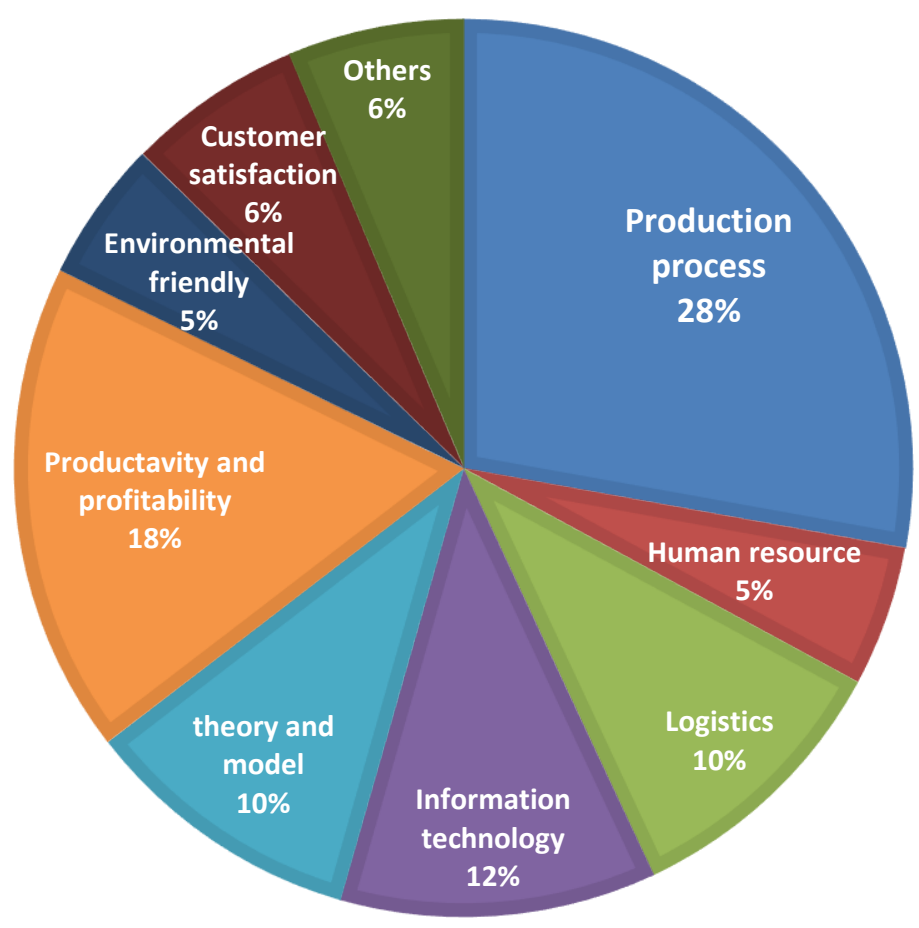

Figure 3 Classification and percentage subdivision of reviewed papers

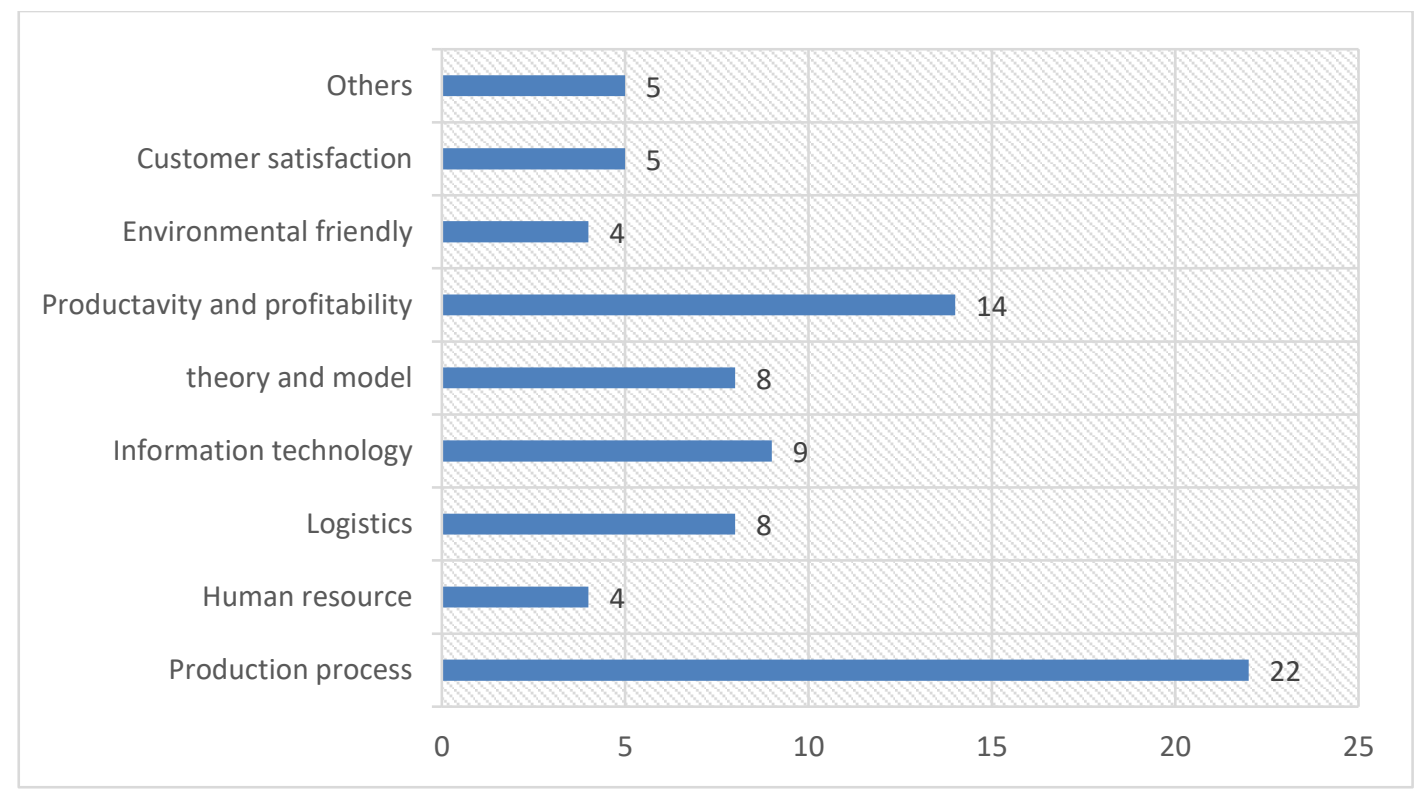

Figure 4 Subdivision of the reviewed papers 


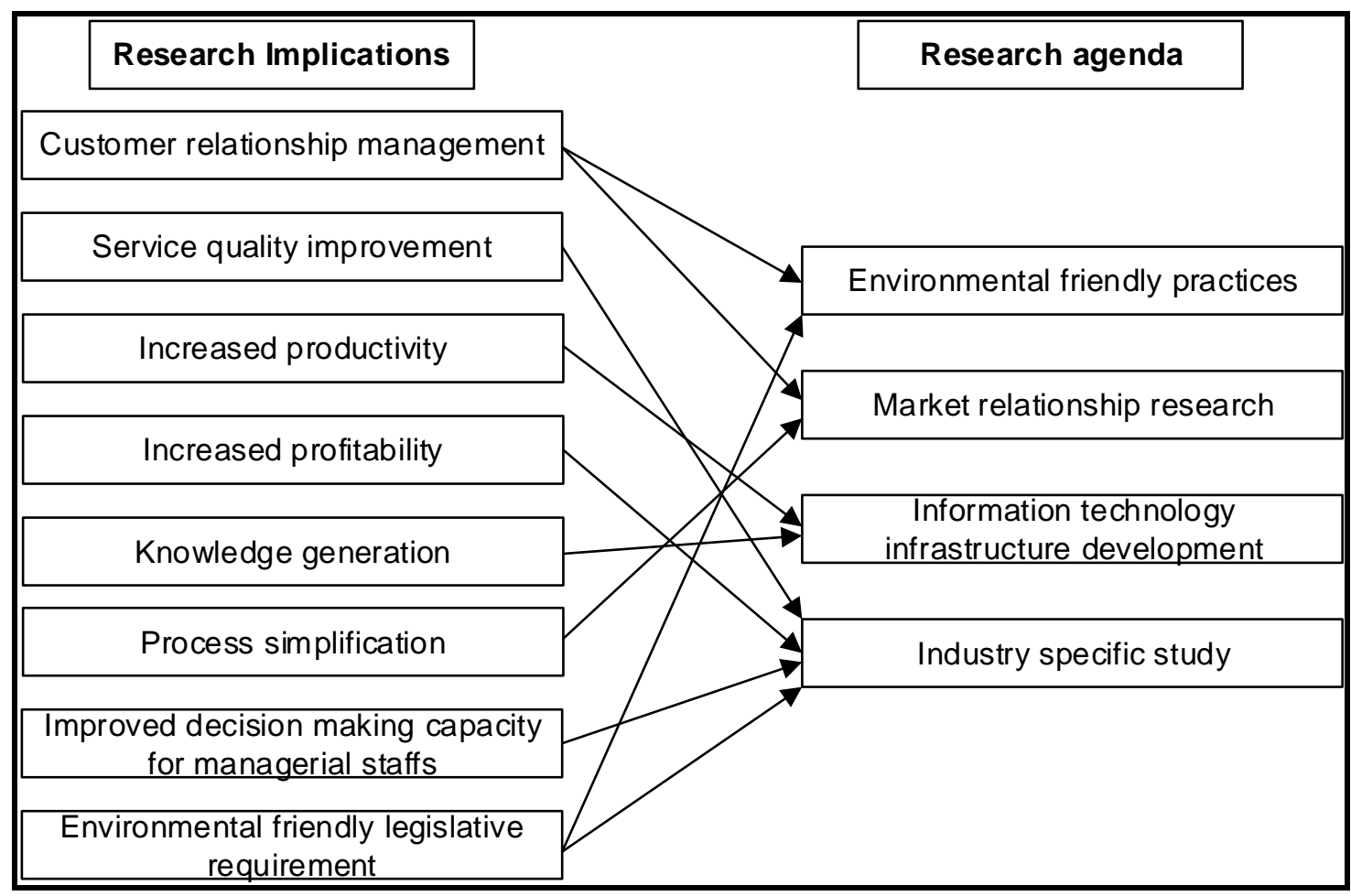

Figure 5 A new agenda for service supply chain research

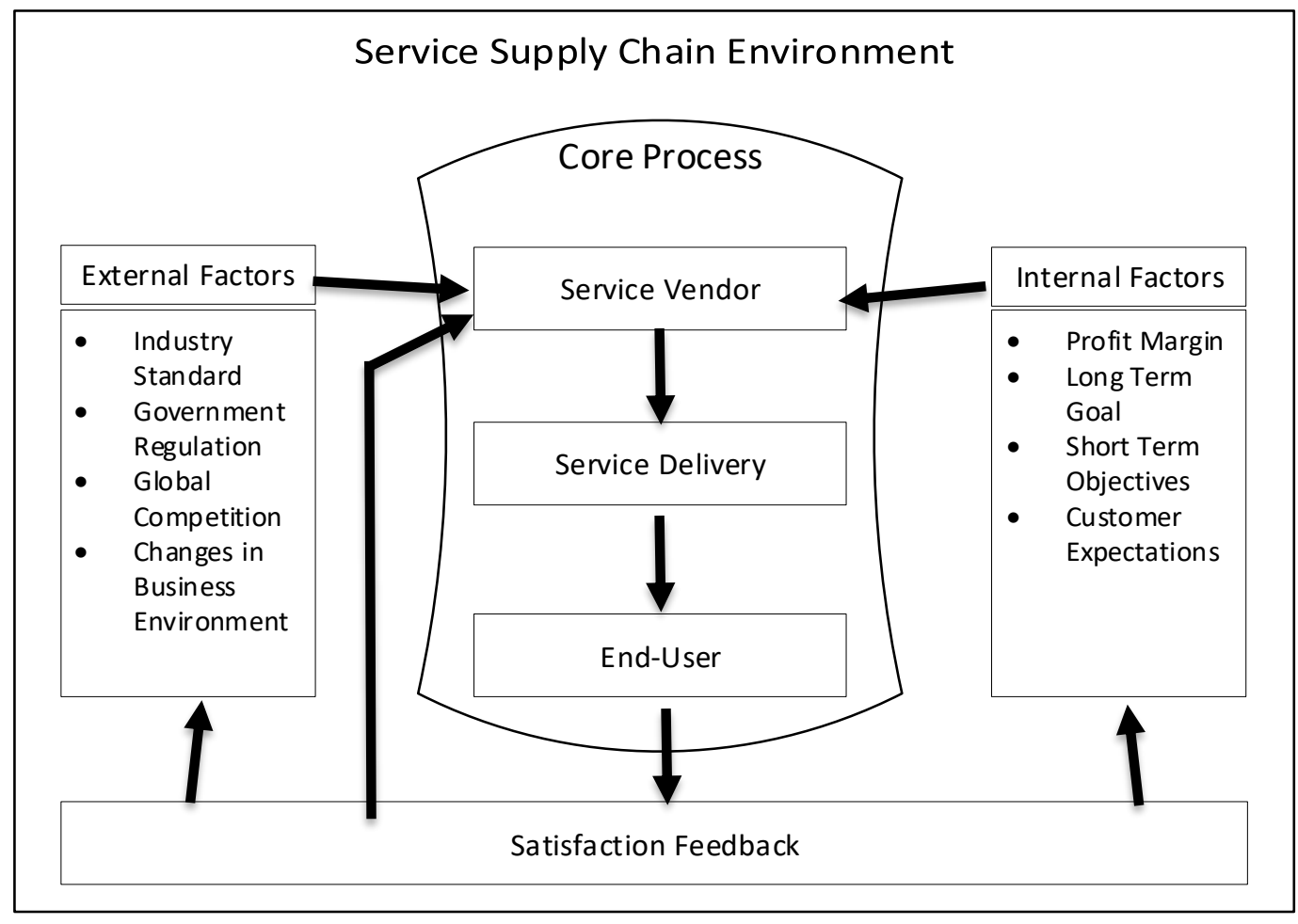

Figure 6 A new conceptual micro framework for service supply chain 


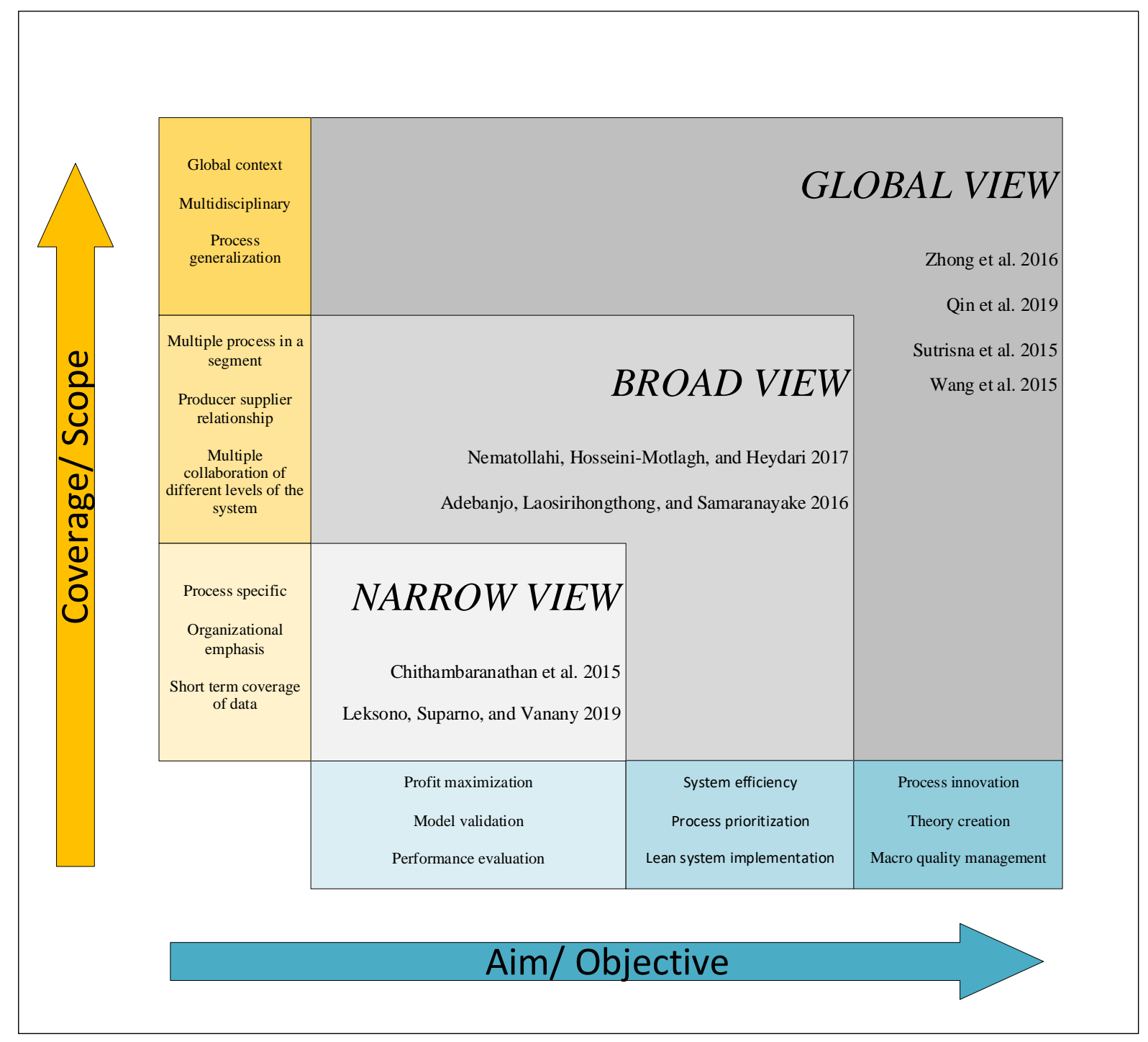

Figure 7 Service supply chain: Author's macro framework 
Table 1 Supply chain management definitions by different authors

\begin{tabular}{|l|l|}
\hline \multicolumn{2}{|l|}{ Authors } \\
\hline 1 & Fisher 1997 \\
\hline 2 & Stevens 1989 \\
\hline 3 & Chen and Paulraj 2004 \\
\hline 4 & Houlihan 1988 \\
\hline 5 & Jones and Riley 1985 \\
\hline 6 & $\begin{array}{l}\text { Melo, Nickel, and Saldanha-Da- } \\
\text { Gama 2009 }\end{array}$ \\
\hline 7 & \begin{tabular}{l} 
Handfield and Nichols 1999 \\
\hline
\end{tabular} \\
\hline
\end{tabular}

Definitions

Supply chain management is a basic terminology created to label the planning and control of materials and information flows with logistics activities, not only within a company but also externally amongst companies (Fisher 1997).

The ideology of handling supply chain management is to harmonize the necessities of the customer with the flow of constituents

from suppliers in order to consequence an equilibrium between what are often seen as contradictory goals of high customer service,

low inventory management, and low unit cost (Stevens 1989).

A representative supply chain is a network of materials, information, and service processing links with the appearances of supply, transformation, and demand (Chen and Paulraj 2004).

Supply chain management calls for, and in the end is subject to, strategic decision making. "Supply" is a pooled objective of essentially every utility in the chain and is of particular deliberate consequence because of its impact on overall costs and market share (Houlihan 1988).

Supply chain manages contracts with the total flow of resources from suppliers through to end consumers (Jones and Riley).

Supply chain management is "the process of planning, implementing and controlling the operation in an efficient way" Melo,

Nickel, and Saldanha-Da-Gama (2009).

Supply chain management can be defined as the holistic management approach for integrating and coordinating the material, information and financial flows along a supply chain (Handfield and Nichols 1999). 
Table 2 Service supply chain definitions by different authors

\begin{tabular}{|c|c|c|}
\hline \multicolumn{2}{|c|}{ Authors } & \multirow{2}{*}{$\begin{array}{l}\text { Definitions } \\
\text { Analogous to the assembly of industrial goods, services fabrication involves the association of several performers; the service } \\
\text { providers, the suppliers of other services or resources needed for the design and delivery of these services and the service clients, all } \\
\text { working together to co-produce value in multifarious value chains or networks (Giannakis 2011a). }\end{array}$} \\
\hline 1 & Giannakis 2011a & \\
\hline 2 & Bhakoo and Chan 2011 & $\begin{array}{l}\text { Service supply chains are characterized by their triadic nature, which is caused by the direct relationships between } \\
\text { the different actors. The nature of these relationships and the level of integration and trust among different actors are major } \\
\text { determinants of the capability of the supply chain to deliver services (Bhakoo and Chan 2011). }\end{array}$ \\
\hline 3 & Baltacioglu et al. 2007 & $\begin{array}{l}\text { Service suppliers, often characterized as the focal firms, pull on the resources of assorted subcontractors and assimilate those } \\
\text { resources into the creation of the "core service" distributed to the end customer (Baltacioglu et al. 2007). }\end{array}$ \\
\hline 4 & $\begin{array}{l}\text { Sengupta, Heiser, and Cook } \\
2006\end{array}$ & $\begin{array}{l}\text { In service supply chains, human labour forms a significant component of the value delivery process and while physical handling of } \\
\text { a product leads to standardized and centralized procedures and controls in manufacturing supply chains, for services this is not } \\
\text { entirely possible as many of the decisions are made locally, and the variation and uncertainties in outputs are higher because of the } \\
\text { human involvement. In addition, the focus of efficiencies in service supply chains is on the management of capacity, flexibility of } \\
\text { resources, information flows, service performance and cash flow management (Sengupta, Heiser, and Cook 2006). }\end{array}$ \\
\hline 5 & Gliatis and Minis 2007 & $\begin{array}{l}\text { Based on this distinction between goods and services, the bibliography proposes a series of features that characterize the supply } \\
\text { chain. During service delivery, the customer participates in the process and can intervene, often to demand additional service of a } \\
\text { particular kind or to request that some aspects of the service be changed. Also, the customer usually depends on the server in order } \\
\text { for the delivery of the service to be complete. This close customer - server interaction reveals another important characteristic } \\
\text { during service delivery: inseparability of production and consumption; that is, the producer - consumer interaction is necessary for } \\
\text { the service to be delivered (Gliatis and Minis 2007). }\end{array}$ \\
\hline 6 & $\begin{array}{l}\text { Li Li, Jiang, Liu, \& } \\
\text { Management, } 2012\end{array}$ & $\begin{array}{l}\text { In this paper, we consider a system of two service providers each with a separate queue. Customers join one queue upon arrival and } \\
\text { can switch in real time between queues to maximize their spot utility that is a function of queue length and price (Li, Jiang, and Liu } \\
\text { 2012). }\end{array}$ \\
\hline
\end{tabular}


Table 3 Review Scope - Opportunity of literature analysis

\begin{tabular}{|c|c|c|c|c|}
\hline Features & \multicolumn{3}{|c|}{ Classifications } \\
\hline Focus & Research outcomes & Research methods & Theories & Application \\
\hline Goal & Integration & Critics & \multicolumn{3}{|c|}{ Methodological } \\
\hline Organization & Historical & Conceptual & \multicolumn{2}{|c|}{ Espousal of position } \\
\hline Perspective & \multicolumn{2}{|c|}{ Natural representation } & Practitioners & General public \\
\hline Audience & Specialized scholars & General scholars & Representative & Central \\
\hline Coverage & Exhaustive & Exhaustive and selective & & \\
\hline
\end{tabular}


Table 4 Keyword search in EBSCOhost, Emerald Insight, ProQuest and Science Direct

\begin{tabular}{|c|c|c|c|c|c|c|}
\hline & & \multirow{2}{*}{ Search terms } & \multicolumn{4}{|c|}{ Databases } \\
\hline & & & EBSCOhost & Emerald & ProQuest & Science Direct \\
\hline \multirow{3}{*}{ "Supply chain" } & AND & "Service activities" & \multirow{12}{*}{25} & \multirow{12}{*}{41} & \multirow{12}{*}{36} & \multirow{12}{*}{42} \\
\hline & AND & "Financial service" & & & & \\
\hline & AND & "Professional service" & & & & \\
\hline \multirow{3}{*}{ "Value chain" } & AND & "Service activities" & & & & \\
\hline & AND & "Financial service" & & & & \\
\hline & AND & "Professional service" & & & & \\
\hline \multirow{3}{*}{ "Systematic coordination" } & AND & "Service activities" & & & & \\
\hline & AND & "Financial service" & & & & \\
\hline & AND & "Professional service" & & & & \\
\hline \multirow{3}{*}{ "Logistics" } & AND & "Service activities" & & & & \\
\hline & AND & "Financial service" & & & & \\
\hline & AND & "Professional service" & & & & \\
\hline Total Net Hits & \multicolumn{6}{|c|}{144} \\
\hline Duplications & \multicolumn{6}{|c|}{65} \\
\hline Result from keyword search & \multicolumn{6}{|c|}{79} \\
\hline
\end{tabular}


Table 5 List of Journals reviewed

\begin{tabular}{|c|c|}
\hline No & Name of the Journal \\
\hline 1 & American Journal Of Agricultural Economics \\
\hline 2 & Annals Of Operations Research \\
\hline 3 & British Journal Of Management \\
\hline 4 & Business Communication Quarterly \\
\hline 5 & Business Horizons \\
\hline 6 & Computer \\
\hline 7 & Computers \& Industrial Engineering \\
\hline 8 & Cornell Hospitality Quarterly \\
\hline 9 & Discrete Dynamics In Nature Society \\
\hline 10 & Energy Policy \\
\hline 11 & European Journal Of Operational Research \\
\hline 12 & European Journal Of Purchasing \& Supply Management \\
\hline 13 & European Management Journal \\
\hline 14 & Expert Systems With Applications \\
\hline 15 & Harvard Business Review \\
\hline 16 & Human Relations \\
\hline 17 & Human Resource Development Review \\
\hline 18 & Ima Journal Of Management Mathematics \\
\hline 19 & Industrial Marketing Management \\
\hline 20 & International Journal Of Logistics Management \\
\hline 21 & International Journal Of Operations \& Production Management \\
\hline 22 & $\begin{array}{l}\text { International Journal Of Physical Distribution \& Logistics } \\
\text { Management }\end{array}$ \\
\hline 23 & International Journal Of Production Economics \\
\hline 24 & International Journal Of Production Research \\
\hline 25 & International Journal Of Service Industry Management \\
\hline 26 & International Journal Of Supply Chain Management \\
\hline 27 & Journal Of Applied Accounting Research \\
\hline 28 & Journal Of Business Ethics \\
\hline 29 & Journal Of Business Logistics \\
\hline 30 & Journal Of Business-To-Business Marketing \\
\hline 31 & Journal Of Cleaner Production \\
\hline 32 & Journal Of Computer Science And Technology \\
\hline 33 & Journal Of Operations Management \\
\hline 34 & Journal Of Scheduling \\
\hline 35 & Journal Of Service Management \\
\hline 36 & Journal Of Supply Chain Management \\
\hline 37 & Journal Of Systems Science And Systems Engineering \\
\hline 38 & Knowledge, Technology \& Policy \\
\hline 39 & Management \& Engineering \\
\hline 40 & Management Decision \\
\hline 41 & Managerial Auditing Journal \\
\hline 42 & Mis Quarterly \\
\hline 43 & Neurocomputing \\
\hline 44 & Operational Research \\
\hline
\end{tabular}




\begin{tabular}{|l|c|}
\hline 45 & Organizational Dynamics \\
\hline 46 & Outlook \\
\hline 47 & Procedia - Social And Behavioral Sciences \\
\hline 48 & Procedia Engineering \\
\hline 49 & Production And Operations Management \\
\hline 50 & Production Operations Management \\
\hline 51 & Production Planning \& Control \\
\hline 52 & Psychological Bulletin \\
\hline 53 & Strategic Management Journal \\
\hline 54 & Supply Chain Management \\
\hline 55 & Supply Chain Management Review \\
\hline 56 & Suble And Sustainable Energy Reviews \\
\hline 57 & Shain Management: An International Journal \\
\hline 58 & The Journal Of Marketing \\
\hline 59 & The Marketing Review \\
\hline 60 & The Service Industries Journal \\
\hline 61 & Transportation Journal \\
\hline 62 & Thternational Journal Of Logistics Management \\
\hline 63 & Review \\
\hline 64 & Transportation Research Part E: Logistics And Transportation \\
\hline 65 & \\
\hline
\end{tabular}


Table 6 Findings from different researchers based on category

\begin{tabular}{|c|c|c|c|}
\hline Category & Focus area & Authors & Findings \\
\hline \multirow[t]{14}{*}{$\begin{array}{l}\text { Production } \\
\text { process }\end{array}$} & $\begin{array}{l}\text { Stochastic optimal control } \\
\text { theory submissions and } \\
\text { acceptance }\end{array}$ & $\begin{array}{l}\text { Anderson and Morrice } \\
(2000)\end{array}$ & $\begin{array}{l}\text { Reorganizing control does not materially } \\
\text { degrade performance, so long as statistics are } \\
\text { shared. }\end{array}$ \\
\hline & $\begin{array}{l}\text { Private hospitals, distribution } \\
\text { and inventory management, } \\
\text { pharmaceuticals industry, } \\
\text { Malaysia }\end{array}$ & $\begin{array}{l}\text { Haszlinna Mustaffa } \\
\text { and Potter (2009) }\end{array}$ & $\begin{array}{l}\text { A framework for the supply chain mechanism } \\
\text { is proposed, based around vendor-managed } \\
\text { inventory. Blocks to achieving this goal are } \\
\text { also identified, including deliberation of } \\
\text { current supply chain management } \\
\text { competences. }\end{array}$ \\
\hline & $\begin{array}{l}\text { Professional services, health, } \\
\text { Iran }\end{array}$ & $\begin{array}{l}\text { Rahimnia and } \\
\text { Moghadasian (2010) }\end{array}$ & $\begin{array}{l}\text { By breaking services into three pipelines, } \\
\text { decoupling points for the supply chain are } \\
\text { identified. The paper also suggests while } \\
\text { conferring legality in a professional service } \\
\text { organization, the important role of human } \\
\text { resources should be emphasized. }\end{array}$ \\
\hline & $\begin{array}{l}\text { Health services research, health } \\
\text { care }\end{array}$ & $\begin{array}{l}\text { De Vries and } \\
\text { Huijsman (2011) }\end{array}$ & $\begin{array}{l}\text { The service supply chain should be regarded as } \\
\text { a cross disciplinary issue for future research } \\
\text { purposes. }\end{array}$ \\
\hline & $\begin{array}{l}\text { Patient care, communication, } \\
\text { integration, }\end{array}$ & $\begin{array}{l}\text { Meijboom, Schmidt- } \\
\text { Bakx, and Westert } \\
(2011)\end{array}$ & $\begin{array}{l}\text { Four major problem categories are } \\
\text { distinguished for the service supply chain: } \\
\text { communication, patient safety, waiting times, } \\
\text { and integration. }\end{array}$ \\
\hline & $\begin{array}{l}\text { Process management, health } \\
\text { care, operations management, }\end{array}$ & $\begin{array}{l}\text { Lillrank, Groop, and } \\
\text { Venesmaa (2011) }\end{array}$ & $\begin{array}{l}\text { Process management in service chains is } \\
\text { appropriate in circumstances where there is an } \\
\text { organized flow with a sufficient volume of } \\
\text { similar repetitions. }\end{array}$ \\
\hline & $\begin{array}{l}\text { Supply chain management, } \\
\text { service operations }\end{array}$ & Giannakis (2011b) & $\begin{array}{l}\text { Six major practices for the construct of service } \\
\text { supply chains are identified: plan, source, } \\
\text { develop, adapt, operate, and recover. }\end{array}$ \\
\hline & $\begin{array}{l}\text { Servitization, demand } \\
\text { management, United Kingdom }\end{array}$ & Braziotis et al. (2013) & $\begin{array}{l}\text { The paper recommends that a mixture of } \\
\text { administration tactics is required by firms } \\
\text { which add services to their portfolio of } \\
\text { traditional product offerings. }\end{array}$ \\
\hline & $\begin{array}{l}\text { After-sales service, supply chain } \\
\text { configuration, durable } \\
\text { consumer goods }\end{array}$ & $\begin{array}{l}\text { Saccani, Johansson, } \\
\text { and Perona (2007). }\end{array}$ & $\begin{array}{l}\text { Configuration choices vary, signifying that no } \\
\text { "one best way", exists. Furthermore, many } \\
\text { firms develop numerous configuration styles. }\end{array}$ \\
\hline & $\begin{array}{l}\text { Operational integration of } \\
\text { supply chain, strategic } \\
\text { integration of supply chain, } \\
\text { product-based service }\end{array}$ & He and Lai (2012) & $\begin{array}{l}\text { This study discovers that operational } \\
\text { incorporation of the supply chain has a direct } \\
\text { and constructive effect on product-based } \\
\text { service, while strategic incorporation has a } \\
\text { direct positive effect on customer action-based } \\
\text { service. }\end{array}$ \\
\hline & $\begin{array}{l}\text { Revenue management, two- } \\
\text { stage game, pricing and } \\
\text { ordering. }\end{array}$ & $\begin{array}{l}\text { Wei, Hu, and Xu } \\
\text { (2013) }\end{array}$ & $\begin{array}{l}\text { Under the leader of the supplier the } \\
\text { competition between the two retailers is } \\
\text { eradicated and each retailer just remits its ideal } \\
\text { magnitude. }\end{array}$ \\
\hline & $\begin{array}{l}\text { Product service system, multi- } \\
\text { attribute utility analysis, } \\
\text { maintenance service level. }\end{array}$ & Kuo and Wang (2012) & $\begin{array}{l}\text { This study investigated altered types of } \\
\text { cohesive maintenance service and used multi- } \\
\text { attribute utility scrutiny to debate the overall } \\
\text { value of maintenance service. }\end{array}$ \\
\hline & $\begin{array}{l}\text { Third party logistics, action } \\
\text { research, cost-to-serve } \\
\text { framework, mathematical } \\
\text { programming }\end{array}$ & $\begin{array}{l}\text { Ross, Jayaraman, and } \\
\text { Robinson (2007). }\end{array}$ & $\begin{array}{l}\text { Details mechanisms used by the global third- } \\
\text { party logistics ( } 3 \mathrm{PL} \text { ) companies to manage } \\
\text { entire supply chains and how supply chain } \\
\text { organizations plan and budget for a process } \\
\text { change. }\end{array}$ \\
\hline & $\begin{array}{l}\text { Telecommunications industry, } \\
\text { backlogs, bullwhip effects, } \\
\text { service variability }\end{array}$ & $\begin{array}{l}\text { Akkermans and Voss } \\
\text { (2013) }\end{array}$ & $\begin{array}{l}\text { The study finds out the idiosyncratic drivers of } \\
\text { the bullwhip effect in services, and the }\end{array}$ \\
\hline
\end{tabular}




\begin{tabular}{|c|c|c|c|}
\hline & & & $\begin{array}{l}\text { managerial actions that can either trigger or } \\
\text { mitigate these bullwhip effects. }\end{array}$ \\
\hline & $\begin{array}{l}\text { Service, interaction, purchasing, } \\
\text { buyer-supplier relationships, } \\
\text { business services }\end{array}$ & $\begin{array}{l}\text { van der Valk and } \\
\text { Wynstra (2014) }\end{array}$ & $\begin{array}{l}\text { The paper discovers that for a technically } \\
\text { homogenous service, major variances in } \\
\text { required collaboration arise as a result of } \\
\text { different usage situations. }\end{array}$ \\
\hline & $\begin{array}{l}\text { Supply chain management, } \\
\text { service }\end{array}$ & $\begin{array}{l}\text { Vandaele and Gemmel } \\
\text { (2007) }\end{array}$ & $\begin{array}{l}\text { PLS specify that the foundations shaping } \\
\text { contentment with the external supplier and } \\
\text { those determining satisfaction with the } \\
\text { business service supplier differ. }\end{array}$ \\
\hline & $\begin{array}{l}\text { Automotive industry, services, } \\
\text { strategic planning }\end{array}$ & $\begin{array}{l}\text { Löfberg, Witell, and } \\
\text { Gustafsson (2010) }\end{array}$ & $\begin{array}{l}\text { A corporation's choice of service tactic looks } \\
\text { to be subjective to its position in the supply } \\
\text { chain. The main explanations for the } \\
\text { modification in strategies seem to relate to } \\
\text { variances in customer demand, the products to } \\
\text { which the services were related, and the size of } \\
\text { the companies. }\end{array}$ \\
\hline & $\begin{array}{l}\text { Outsourcing, services supply } \\
\text { chain, service provider }\end{array}$ & $\begin{array}{l}\text { Demirkan and Cheng } \\
\text { (2008) }\end{array}$ & $\begin{array}{l}\text { An effective decentralized mechanism is } \\
\text { needed to achieve the goal of maximizing } \\
\text { overall supply chain performance. }\end{array}$ \\
\hline & $\begin{array}{l}\text { Service outsourcing, supply } \\
\text { chain efficiency, channel power } \\
\text { structure }\end{array}$ & $\begin{array}{l}\text { Bian, Lai, and Hua } \\
\text { (2017) }\end{array}$ & $\begin{array}{l}\text { The paper investigates the impact of service } \\
\text { outsourcing on pricing and service, and found } \\
\text { that lower prices and higher service levels can, } \\
\text { but never simultaneously, occur in a } \\
\text { decentralized channel compared to the } \\
\text { integrated channel. }\end{array}$ \\
\hline & $\begin{array}{l}\text { Multinational supply chain } \\
\text { organizations, organizational } \\
\text { design change, organizational } \\
\text { change theory }\end{array}$ & Roh et al. (2017) & $\begin{array}{l}\text { This study identifies and elaborates internal } \\
\text { and external drivers of organizational design } \\
\text { change in the context of multinational supply } \\
\text { chain management organizations. }\end{array}$ \\
\hline & $\begin{array}{l}\text { Manufacturing service supply } \\
\text { chain, multi-objective, quality of } \\
\text { service }\end{array}$ & Zhang et al. (2017) & $\begin{array}{l}\text { This paper proposes a new fuzzy quality of } \\
\text { service (QoS)-aware multi-objective } \\
\text { mathematical model for evaluating the global } \\
\text { QoS value of a manufacturing service supply } \\
\text { chain. }\end{array}$ \\
\hline & $\begin{array}{l}\text { Collaborative networked } \\
\text { organisation, product-service } \\
\text { systems, value co-creation, } \\
\text { complex networks, conceptual } \\
\text { modelling, graph theory }\end{array}$ & $\begin{array}{l}\text { Durugbo and Riedel } \\
\text { (2013) }\end{array}$ & $\begin{array}{l}\text { A theoretical model is projected for assessing } \\
\text { the readiness of concerted networked } \\
\text { organisations for product-service system } \\
\text { distribution. }\end{array}$ \\
\hline $\begin{array}{l}\text { Productivity and } \\
\text { profitability }\end{array}$ & $\begin{array}{l}\text { Supply chain management, } \\
\text { supplier relations, financial } \\
\text { services }\end{array}$ & $\begin{array}{l}\text { Field and Meile } \\
(2008)\end{array}$ & $\begin{array}{l}\text { Use of information technology, electronic } \\
\text { information-sharing, supplier type, and firm } \\
\text { size, better supplier relations are associated } \\
\text { with gratification with overall supplier } \\
\text { enactment. }\end{array}$ \\
\hline & $\begin{array}{l}\text { Public warehouse, WPSS, } \\
\text { service capability, maturity, } \\
\text { analytical target cascading }\end{array}$ & Cao and Jiang (2013) & $\begin{array}{l}\text { This paper provides guidance for both } \\
\text { investors who want to figure a public } \\
\text { warehouse and administrators who want to } \\
\text { uninterruptedly progress an existing one. }\end{array}$ \\
\hline & $\begin{array}{l}\text { Manpower planning, service } \\
\text { providers, retailers, financial } \\
\text { crisis }\end{array}$ & $\begin{array}{l}\text { de Leeuw and Wiers } \\
(2015)\end{array}$ & $\begin{array}{l}\text { The study outlines how higher functioning } \\
\text { planning is a key approach to counter the } \\
\text { effects of the financial calamity. }\end{array}$ \\
\hline & $\begin{array}{l}\text { Supply chain integration, } \\
\text { financial performance, } \\
\text { structural equations modelling }\end{array}$ & Vickery et al. (2003) & $\begin{array}{l}\text { The study exhibited positive direct associations } \\
\text { between (1) unified information technologies } \\
\text { and supply chain integration, (2) supply chain } \\
\text { incorporation and customer service, and (3) } \\
\text { customer service and firm enactment. }\end{array}$ \\
\hline & $\begin{array}{l}\text { Supply chain management, } \\
\text { agency theory, risk } \\
\text { management, service industries, } \\
\text { service supply chains }\end{array}$ & $\begin{array}{l}\text { Selviaridis and } \\
\text { Norrman }(2014)\end{array}$ & $\begin{array}{l}\text { The study finds the following factors used to } \\
\text { influence provider willingness to bear PBC- } \\
\text { induced risk: performance attributability within } \\
\text { the service supply chain; relational governance } \\
\text { in service supply chain relationships; provider } \\
\text { risk and reward balancing; and provider ability } \\
\text { to transfer risk to sub-contractors. }\end{array}$ \\
\hline
\end{tabular}




\begin{tabular}{|c|c|c|c|}
\hline & $\begin{array}{l}\text { Professional service supply } \\
\text { chain, high performance work } \\
\text { systems, professional service } \\
\text { firms, teams }\end{array}$ & Fu et al. (2013) & $\begin{array}{l}\text { The outcomes specify the positive link } \\
\text { between HPWS and the skilled service supply } \\
\text { chain performance. }\end{array}$ \\
\hline & $\begin{array}{l}\text { Financial institutions, open } \\
\text { systems }\end{array}$ & Fairchild (2005) & $\begin{array}{l}\text { Drivers for intelligent matching resolutions } \\
\text { have the ability to link financial matching } \\
\text { events to other supply chain activities. }\end{array}$ \\
\hline & $\begin{array}{l}\text { System dynamic, business } \\
\text { games }\end{array}$ & $\begin{array}{l}\text { Anderson and Morrice } \\
(2000)\end{array}$ & $\begin{array}{l}\text { Administrators can effectively use end-user } \\
\text { demand information to reduce backlog and } \\
\text { capacity adjustment costs. }\end{array}$ \\
\hline & $\begin{array}{l}\text { Service operations, } \\
\text { amplification, case study }\end{array}$ & $\begin{array}{l}\text { Akkermans and Vos } \\
\text { (2003) }\end{array}$ & $\begin{array}{l}\text { The study finds a new root cause for } \\
\text { amplification: interactions of high workloads } \\
\text { and reduced process quality that reinforce each } \\
\text { other once workloads pass a certain threshold. }\end{array}$ \\
\hline & $\begin{array}{l}\text { Service requirements, financial } \\
\text { flow }\end{array}$ & Martin et al. (2017) & $\begin{array}{l}\text { Focuses on finding the reasons to involve } \\
\text { financial service providers through supply } \\
\text { chain finance practices in the integrated supply } \\
\text { chain. }\end{array}$ \\
\hline & $\begin{array}{l}\text { Bidirectional option contracts, } \\
\text { risk management coordination, } \\
\text { service requirements }\end{array}$ & $\begin{array}{l}\text { Chen, Wan, and Wang } \\
\text { (2017) }\end{array}$ & $\begin{array}{l}\text { The study finds that the service level with } \\
\text { bidirectional option contracts is beneficial to } \\
\text { both retailers and suppliers. }\end{array}$ \\
\hline & $\begin{array}{l}\text { Revenue sharing contracts, } \\
\text { service requirement, service } \\
\text { contracts }\end{array}$ & Hu and Feng (2017) & $\begin{array}{l}\text { This paper models a supply chain of service } \\
\text { requirements and finds that the buyer's optimal } \\
\text { ordering policies are not only affected by } \\
\text { demand uncertainty, but also by service } \\
\text { requirements. }\end{array}$ \\
\hline & $\begin{array}{l}\text { Game theory, channel } \\
\text { leadership, agri-product, } \\
\text { service level }\end{array}$ & Yu and Xiao (2017) & $\begin{array}{l}\text { This study develops two Stackelberg models to } \\
\text { investigate the pricing and service level } \\
\text { decisions of a fresh agro-products supply chain } \\
\text { and finds that that when the service sensitivity } \\
\text { is low, each player can obtain a higher profit } \\
\text { under the logistics provider. }\end{array}$ \\
\hline & $\begin{array}{l}\text { Sustainable supply chains, } \\
\text { learning capabilities, } \\
\text { innovation, service providers }\end{array}$ & Rossi et al. (2013) & $\begin{array}{l}\text { The systematic literature review improves the } \\
\text { prevailing literature by drawing on three bodies } \\
\text { of information, i.e. logistics service providers, } \\
\text { eco-efficiency and logistics innovation, and } \\
\text { puts them into a solitary agenda. }\end{array}$ \\
\hline $\begin{array}{l}\text { Theory and } \\
\text { model } \\
\text { generation }\end{array}$ & $\begin{array}{l}\text { Nurse rostering, hospital } \\
\text { personnel scheduling }\end{array}$ & Burke et al. (2004) & $\begin{array}{l}\text { Focuses on the metiers and faintness of the } \\
\text { literature to summary the key issues that need } \\
\text { addressing in future nurse rostering. }\end{array}$ \\
\hline & $\begin{array}{l}\text { Offshoring, service, knowledge, } \\
\text { outsourcing, Information }\end{array}$ & $\begin{array}{l}\text { Youngdahl, } \\
\text { Ramaswamy, and } \\
\text { Verma (2008) }\end{array}$ & $\begin{array}{l}\text { The paper provides a site for presenting } \\
\text { standpoints on the operational and cross- } \\
\text { disciplinary encounters and openings in the } \\
\text { area of service and knowledge offshoring. }\end{array}$ \\
\hline & $\begin{array}{l}\text { Service industries, conceptual } \\
\text { framework, research agenda }\end{array}$ & $\begin{array}{l}\text { Baltacioglu et al. } \\
\text { (2007) }\end{array}$ & $\begin{array}{l}\text { This research develops a new model for service } \\
\text { supply chains and applies it to the healthcare } \\
\text { business. }\end{array}$ \\
\hline & $\begin{array}{l}\text { Quality management, suppliers, } \\
\text { agency theory }\end{array}$ & Zu and Kaynak (2012) & $\begin{array}{l}\text { This paper finds that rather than trusting on } \\
\text { one broad supply chain quality management } \\
\text { approach for all suppliers, firms need to choose } \\
\text { different management instruments for different } \\
\text { suppliers based on the prominent attributes of } \\
\text { individual suppliers and their relationships } \\
\text { with the buyers. }\end{array}$ \\
\hline & $\begin{array}{l}\text { Service operations, service } \\
\text { delivery systems }\end{array}$ & $\begin{array}{l}\text { Youngdahl and } \\
\text { Loomba (2000) }\end{array}$ & $\begin{array}{l}\text { The purpose of this paper is to extend the } \\
\text { concept of the service factory to global supply } \\
\text { chains. }\end{array}$ \\
\hline & $\begin{array}{l}\text { Visibility, industrial services, } \\
\text { asset management, operations } \\
\text { management }\end{array}$ & $\begin{array}{l}\text { Holmström, Brax, and } \\
\text { Ala-Risku (2010) }\end{array}$ & $\begin{array}{l}\text { An illustrative model of three separate } \\
\text { provider-customer constellations is } \\
\text { conceptualized that reflects specific types of } \\
\text { visibility: cooperative service supply chain } \\
\text { management, condition-based maintenance as }\end{array}$ \\
\hline
\end{tabular}




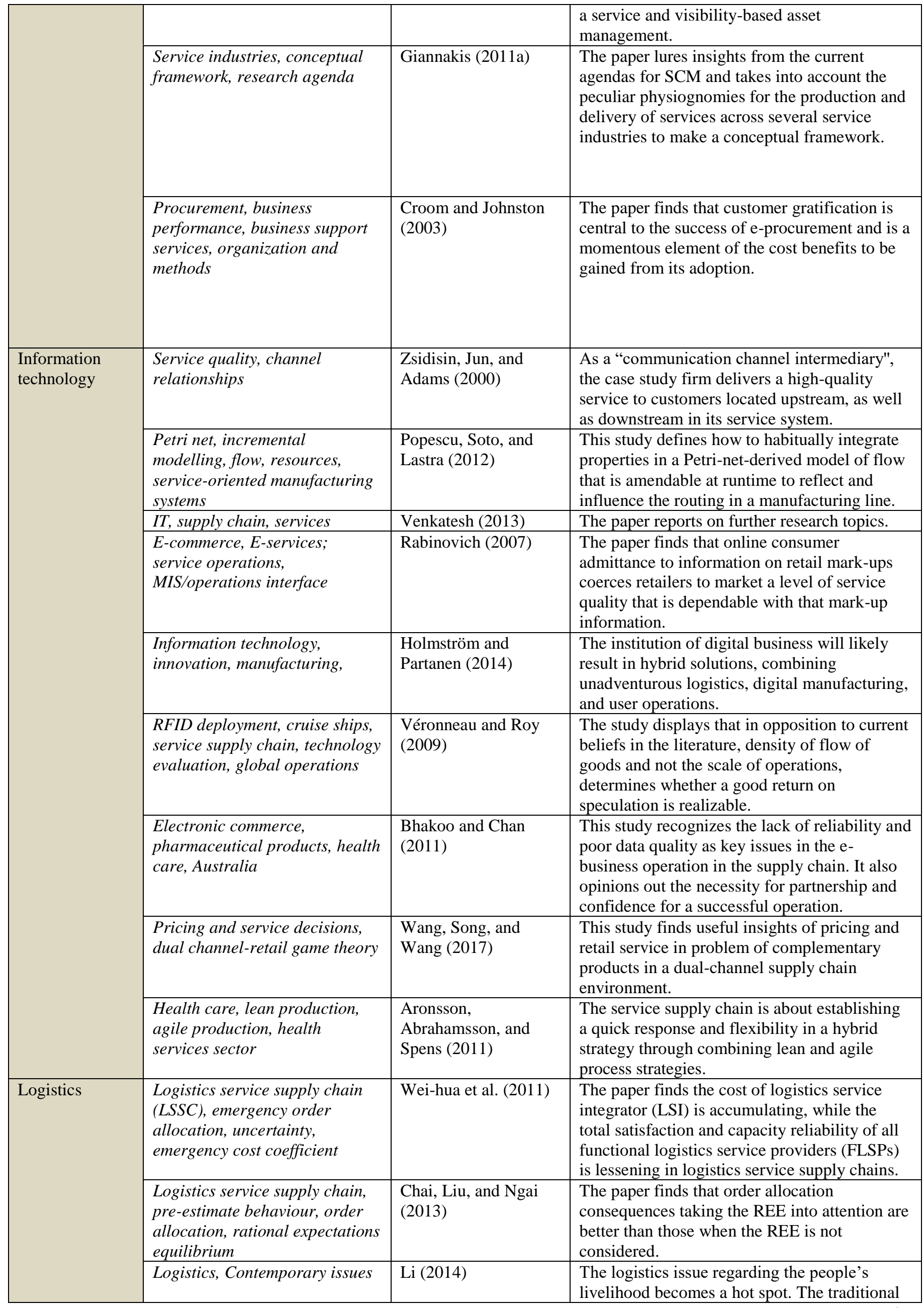




\begin{tabular}{|c|c|c|c|}
\hline & & & $\begin{array}{l}\text { research in this regard is related to perishable } \\
\text { product, fashion product, and electronic } \\
\text { product, which have short life cycle. } \\
\text { Nowadays, such topics might include city } \\
\text { logistics, emergency logistics, and agriculture } \\
\text { supply chain. }\end{array}$ \\
\hline & $\begin{array}{l}\text { Relational benefits, logistical } \\
\text { service, long-term business } \\
\text { relationship }\end{array}$ & Li et al. (2012) & $\begin{array}{l}\text { The paper finds that the building of a long- } \\
\text { term association is facilitated by trust and } \\
\text { commitment from manufacturers. }\end{array}$ \\
\hline & $\begin{array}{l}\text { Quality guarantee, logistics } \\
\text { service supply chain, quality } \\
\text { supervision effort, performance } \\
\text { loss rate }\end{array}$ & Liu and Xie (2013) & $\begin{array}{l}\text { The paper concludes that optimal quality defect } \\
\text { guarantee of the FLSP increases as customer } \\
\text { punishment upsurges, and drops as the } \\
\text { elasticity of the customer demand for the } \\
\text { quality defect guarantee increases. }\end{array}$ \\
\hline & $\begin{array}{l}\text { Third party logistics }(3 P L) \\
\text { budget-constrained retailer }\end{array}$ & Chen and Cai (2011) & $\begin{array}{l}\text { The paper finds that the control role and } \\
\text { supplier credit models can outclass the classic } \\
\text { newsvendor model without budget restrictions. }\end{array}$ \\
\hline & $\begin{array}{l}\text { Logistics service supply chain, } \\
\text { order allocation, multi-objective }\end{array}$ & $\begin{array}{l}\text { Qin, Su, and Huang } \\
\text { (2017) }\end{array}$ & $\begin{array}{l}\text { A two-echelon logistic service supply chain is } \\
\text { studied, and considers demand updating and } \\
\text { the fairness preferences integrator to maximise } \\
\text { profit. }\end{array}$ \\
\hline & $\begin{array}{l}\text { Service level, contract } \\
\text { management }\end{array}$ & $\begin{array}{l}\text { Sieke, Seifert, and } \\
\text { Thonemann (2012) }\end{array}$ & $\begin{array}{l}\text { The paper looks into how the supplier responds } \\
\text { to the contracts and how the contract } \\
\text { limitations can be chosen. }\end{array}$ \\
\hline \multirow[t]{4}{*}{$\begin{array}{l}\text { Human resource } \\
\text { related }\end{array}$} & $\begin{array}{l}\text { Job satisfaction, human } \\
\text { resource in supply chain, } \\
\text { person-organization fit }\end{array}$ & Maloni et al. (2017) & $\begin{array}{l}\text { Job satisfaction and industry commitments are } \\
\text { impacted differently across workforce levels in } \\
\text { supply chain. }\end{array}$ \\
\hline & $\begin{array}{l}\text { Pharmaceutical supply chain, } \\
\text { service level, social } \\
\text { responsibility }\end{array}$ & $\begin{array}{l}\text { Nematollahi, } \\
\text { Hosseini-Motlagh, and } \\
\text { Heydari (2017) } \\
\end{array}$ & $\begin{array}{l}\text { The paper finds that collaborative decision- } \\
\text { making on visit interval and service level could } \\
\text { be beneficial, socially and economically. }\end{array}$ \\
\hline & $\begin{array}{l}\text { Healthcare supply chain } \\
\text { coordination, integration }\end{array}$ & $\begin{array}{l}\text { Mandal and Jha } \\
\text { (2017) }\end{array}$ & $\begin{array}{l}\text { The paper identifies that collaboration } \\
\text { planning, execution and decision-making in } \\
\text { hospitals and suppliers in healthcare enhance } \\
\text { operational performance. }\end{array}$ \\
\hline & $\begin{array}{l}\text { Energy efficiency, retrofitting, } \\
\text { stakeholder theory, environment }\end{array}$ & $\begin{array}{l}\text { Genovese, Koh, and } \\
\text { Acquaye (2013) }\end{array}$ & $\begin{array}{l}\text { The paper identified three ideal types of supply } \\
\text { chain configurations based on the size and } \\
\text { scope of energy efficiency. }\end{array}$ \\
\hline \multirow[t]{4}{*}{$\begin{array}{l}\text { Environmental } \\
\text { friendly practice }\end{array}$} & $\begin{array}{l}\text { Environmental performance } \\
\text { evaluation, grey MCDM } \\
\text { approach }\end{array}$ & $\begin{array}{l}\text { Chithambaranathan et } \\
\text { al. (2015) }\end{array}$ & $\begin{array}{l}\text { A grey-based hybrid agenda for evaluating the } \\
\text { ecological performance of service supply } \\
\text { chains is projected by integrating grey-based } \\
\text { techniques with ELECTRE and VIKOR } \\
\text { tactics. }\end{array}$ \\
\hline & $\begin{array}{l}\text { Resource efficiency, service } \\
\text { delivery system, services } \\
\text { management, eco-friendly } \\
\text { service concept, service } \\
\text { coproduction, signalling effect }\end{array}$ & $\begin{array}{l}\text { Zhang, Joglekar, and } \\
\text { Verma (2014) }\end{array}$ & $\begin{array}{l}\text { The paper indicates that dependable eco- } \\
\text { certifications achieve the signalling effect. }\end{array}$ \\
\hline & $\begin{array}{l}\text { Marketing mix, customer } \\
\text { satisfaction }\end{array}$ & Keller et al. (2006) & $\begin{array}{l}\text { A positive linkage is found between the } \\
\text { internal marketing mix and internal customer } \\
\text { performance in service supply chains. }\end{array}$ \\
\hline & $\begin{array}{l}\text { Service industries, supply chain } \\
\text { management }\end{array}$ & Sampson (2000) & $\begin{array}{l}\text { A customer-supplier duality is discovered as it } \\
\text { pertains to service supply chain management, } \\
\text { including practical and administrative } \\
\text { implications. }\end{array}$ \\
\hline \multirow[t]{2}{*}{$\begin{array}{l}\text { Customer } \\
\text { satisfaction } \\
\text { related }\end{array}$} & $\begin{array}{l}\text { After-sales service, uncertainty, } \\
\text { Game Theory, marketing- } \\
\text { operations interface }\end{array}$ & $\begin{array}{l}\text { Kurata and Nam } \\
(2013)\end{array}$ & $\begin{array}{l}\text { The paper finds out a firm's effort to provide } \\
\text { efficient service operations will increase the } \\
\text { chance of accidental out performance. }\end{array}$ \\
\hline & $\begin{array}{l}\text { Service quality coordination, } \\
\text { online supply chain, Game } \\
\text { Theory }\end{array}$ & Qin et al. (2017) & $\begin{array}{l}\text { This paper proposes two models, which } \\
\text { consider individual rationality and fairness } \\
\text { preferences of members and designs } \\
\text { coordination contracts in a decentralized online } \\
\text { shopping service supply chain. }\end{array}$ \\
\hline
\end{tabular}




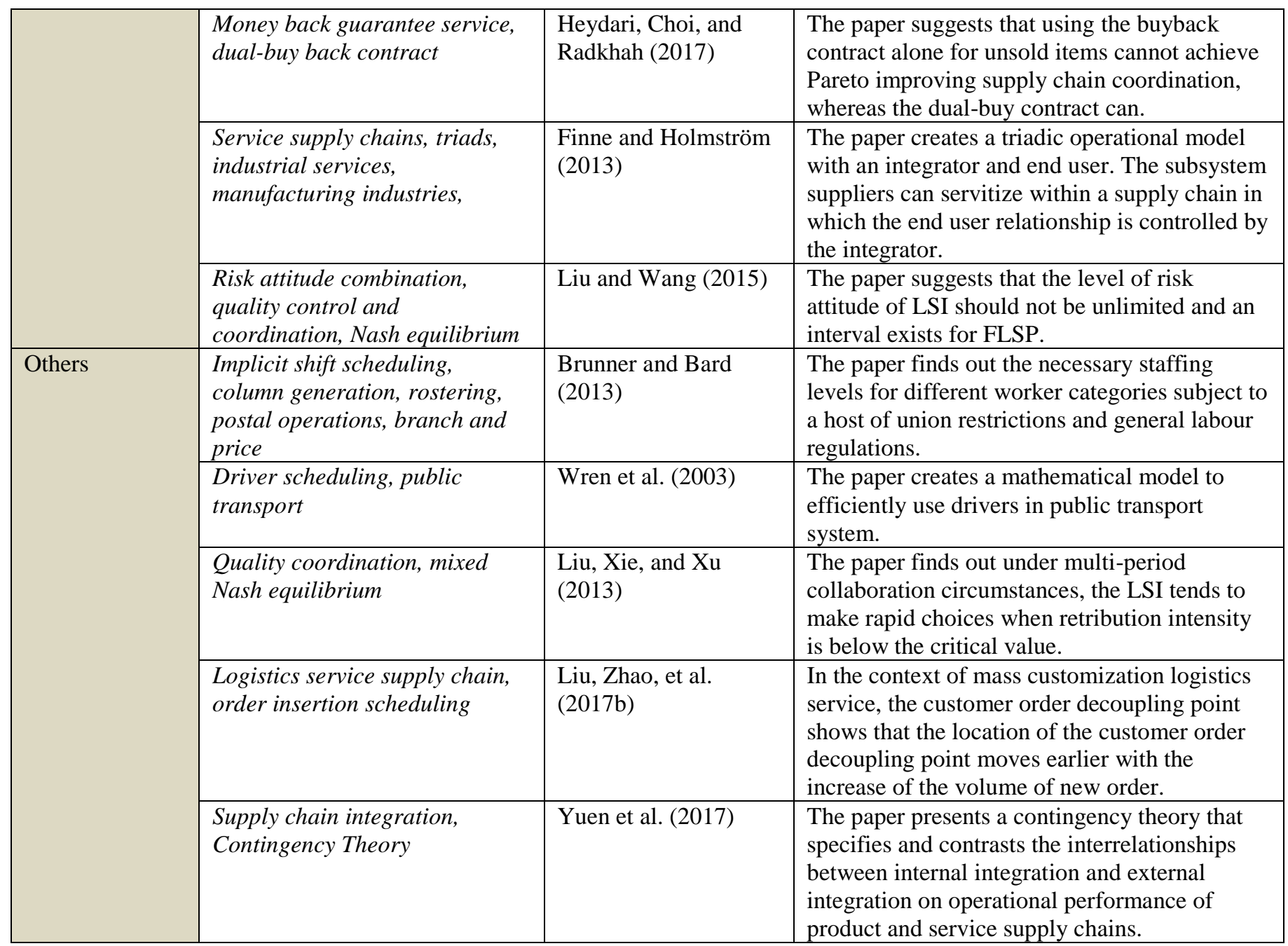




\section{References}

Adebanjo, Dotun, Tritos Laosirihongthong, and Premaratne Samaranayake. 2016. "Prioritizing lean supply chain management initiatives in healthcare service operations: a fuzzy AHP approach." Production Planning \& Control 27 (12):953-66.

Aitken, James, Paul Childerhouse, Eric Deakins, and Denis Towill. 2015. "Comparative study of manufacturing and service supply chain uncertainty." Forthcoming in International Journal of Logistics Management.

Akkermans, Henk, and Bart Vos. 2003. "Amplification in service supply chains: An exploratory case study from the telecom industry." Production and Operations management 12 (2):204-23.

Akkermans, Henk, and Chris Voss. 2013. "The service bullwhip effect." International Journal of Operations \& Production Management 33 (6):765-88.

AL-Shboul, Moh'd AR. 2017. "Infrastructure framework and manufacturing supply chain agility: the role of delivery dependability and time to market." Supply Chain Management: An International Journal 22 (2).

Alghisi, Andrea, Nicola \%J Production Planning Saccani, and Control. 2015. "Internal and external alignment in the servitization journey-overcoming the challenges." 26 (14-15):1219-32.

Anderson, Edward G, and Douglas J Morrice. 2000. "A Simulation Game for Teaching Service-Oriented Supply Chain Management: Does Information Sharing Help Managers With Service Capacity Decisions?" Production and Operations management 9 (1):40-55.

Anklesaria, Jimmy. 2008. Supply chain cost management: the AIM \& DRIVE process for achieving extraordinary results: AMACOM Div American Mgmt Assn.

Aronsson, Håkan, Mats Abrahamsson, and Karen Spens. 2011. "Developing lean and agile health care supply chains." Supply Chain Management: An International Journal 16 (3):176-83.

Asgari, Nasrin, Ehsan Nikbakhsh, Alex Hill, and Reza Zanjirani Farahani. 2016. "Supply chain management 19822015: a review." IMA Journal of Management Mathematics 27 (3):353-79. doi: 10.1093/imaman/dpw004.

Baker, Michael J. 2000. "Writing a literature review." The Marketing Review 1 (2):219-47.

Baltacioglu, Tuncdan, Erhan Ada, Melike D Kaplan, Oznur Yurt And, and Y Cem Kaplan. 2007. "A new framework for service supply chains." The Service Industries Journal 27 (2):105-24.

Beamon, Benita M. 1999. "Measuring supply chain performance." International Journal of Operations \& Production Management 19 (3):275-92.

Bem, Daryl J. 1995. "Writing a review article for Psychological Bulletin." Psychological Bulletin 118 (2):172.

Bhakoo, Vikram, and Caroline Chan. 2011. "Collaborative implementation of e-business processes within the healthcare supply chain: the Monash Pharmacy Project." Supply Chain Management: An International Journal 16 (3):184-93.

Bian, Junsong, Kin Keung Lai, and Zhongsheng Hua. 2017. "Service outsourcing under different supply chain power structures." Annals of Operations Research 248 (1-2):123-42.

Boon-itt, Sakun, Chee Yew Wong, and Christina W. Y. Wong. 2017. "Service supply chain management process capabilities: Measurement development." International Journal of Production Economics 193:1-11. doi: http://dx.doi.org/10.1016/j.ijpe.2017.06.024.

Borodin, Valeria, Jean Bourtembourg, Faicel Hnaien, and Nacima Labadie. 2016. "Handling uncertainty in agricultural supply chain management: a state of the art." European journal of operational research 254 (2):348-59.

Brandenburg, Marcus, Kannan Govindan, Joseph Sarkis, and Stefan Seuring. 2014. "Quantitative models for sustainable supply chain management: Developments and directions." European journal of operational research 233 (2):299-312. doi: http://dx.doi.org/10.1016/j.ejor.2013.09.032.

Braziotis, Christos, Michael Bourlakis, Helen Rogers, and James Tannock. 2013. "Supply chains and supply networks: distinctions and overlaps." Supply Chain Management: An International Journal 18 (6):644-52. doi: doi:10.1108/SCM-07-2012-0260.

Brunner, Jens O, and Jonathan F Bard. 2013. "Flexible weekly tour scheduling for postal service workers using a branch and price." Journal of scheduling 16 (1):129-49.

Burgess, Kevin, Prakash J Singh, and Rana Koroglu. 2006. "Supply chain management: a structured literature review and implications for future research." International Journal of Operations \& Production Management 26 (7):703-29.

Burke, Edmund K, Patrick De Causmaecker, Greet Vanden Berghe, and Hendrik Van Landeghem. 2004. "The state of the art of nurse rostering." Journal of scheduling 7 (6):441-99. 
Bustinza, Oscar F., Glenn C. Parry, and Ferran Vendrell-Herrero. 2013. "Supply and demand chain management: The effect of adding services to product offerings." Supply Chain Management: An International Journal 18 (6):618-29.

Cao, Wei, and Pingyu Jiang. 2013. "Modelling on service capability maturity and resource configuration for public warehouse product service systems." International Journal of Production Research 51 (6):1898-921.

Carter, Craig R., Dale S. Rogers, and Thomas Y. Choi. 2015. "Toward the Theory of the Supply Chain." Journal of Supply Chain Management 51 (2):89-97. doi: 10.1111/jscm.12073.

Carter, R.J., and P. Price. 1993. Integrated Materials Management: Pitman.

Chai, Junyi, James N. K. Liu, and Eric W. T. Ngai. 2013. "Application of decision-making techniques in supplier selection: A systematic review of literature." Expert Systems with Applications 40 (10):3872-85. doi: http://dx.doi.org/10.1016/j.eswa.2012.12.040.

Chen, Injazz J, and Antony Paulraj. 2004. "Towards a theory of supply chain management: the constructs and measurements." Journal of Operations Management 22 (2):119-50.

Chen, Xiangfeng, and Gangshu George Cai. 2011. "Joint logistics and financial services by a 3PL firm." European journal of operational research 214 (3):579-87.

Chen, Xu, Nana Wan, and Xiaojun Wang. 2017. "Flexibility and coordination in a supply chain with bidirectional option contracts and service requirement." International Journal of Production Economics 193:183-92.

Chithambaranathan, P, Nachiappan Subramanian, Angappa Gunasekaran, and PL K Palaniappan. 2015. "Service supply chain environmental performance evaluation using grey based hybrid MCDM approach." International Journal of Production Economics 166:163-76.

Chopra, Sunil, and Peter Meindl. 2007. Supply chain management : strategy, planning, and operation: Upper Saddle River, N.J. : Prentice Hall

Choudhury, Tonmoy T, and Kevin James Daly. 2019. "A note on contemporary literature of risk and risk management in banking." WSEAS Transactions on Business and Economics 16:107-19.

Colicchia, Claudia, and Fernanda Strozzi. 2012. "Supply chain risk management: a new methodology for a systematic literature review." Supply Chain Management: An International Journal 17 (4):403-18. doi: doi:10.1108/13598541211246558.

Cooper, Harris M. 1988. "Organizing knowledge syntheses: A taxonomy of literature reviews." Knowledge, Technology \& Policy 1 (1):104-26.

Croom, Simon, and Robert Johnston. 2003. "E-service: enhancing internal customer service through e-procurement." International Journal of Service Industry Management 14 (5):539-55.

Croom, Simon, Pietro Romano, and Mihalis Giannakis. 2000. "Supply chain management: an analytical framework for critical literature review." European journal of purchasing \& supply management 6 (1):67-83.

Crotty, Michael. 1998. The foundations of social research: Meaning and perspective in the research process: Sage.

David, Robert J., and Shin-Kap Han. 2004. "A systematic assessment of the empirical support for transaction cost economics." Strategic management journal 25 (1):39-58. doi: 10.1002/smj.359.

de Leeuw, Sander, and Vincent CS Wiers. 2015. "Warehouse manpower planning strategies in times of financial crisis: evidence from logistics service providers and retailers in the Netherlands." Production Planning \& Control 26 (4):328-37.

De Vries, Jan, and Robbert Huijsman. 2011. "Supply chain management in health services: an overview." Supply Chain Management: An International Journal 16 (3):159-65.

Demirkan, Haluk, and Hsing Kenneth Cheng. 2008. "The risk and information sharing of application services supply chain." European journal of operational research 187 (3):765-84.

Du, Xiaoxue, Liang Lu, Thomas Reardon, and David Zilberman. 2016. "Economics of Agricultural Supply Chain Design: A Portfolio Selection Approach." American Journal of Agricultural Economics 98 (5):1377-88.

Dubey, Rameshwar, Rameshwar Dubey, Angappa Gunasekaran, Angappa Gunasekaran, Stephen J Childe, Stephen J Childe, Thanos Papadopoulos, Thanos Papadopoulos, Samuel Fosso Wamba, and Samuel Fosso Wamba. 2017. "World class sustainable supply chain management: critical review and further research directions."

The International Journal of Logistics Management 28 (2):332-62.

Durugbo, Christopher, and Johann CKH Riedel. 2013. "Readiness assessment of collaborative networked organisations for integrated product and service delivery." International Journal of Production Research 51 (2):598-613.

Economist Intelligence Unit. 2013. "EIU GDP Data."

Ellram, Lisa M, Wendy L Tate, and Corey Billington. 2004. "Understanding and managing the services supply chain." Journal of Supply Chain Management 40 (3):17-32.

Ellram, Lisa M., and Martha C. Cooper. 2014. "Supply Chain Management: It's All About the Journey, Not the Destination." Journal of Supply Chain Management 50 (1):8-20. doi: 10.1111/jscm.12043. 
Fairchild, Alea. 2005. "Intelligent matching: integrating efficiencies in the financial supply chain." Supply Chain Management: An International Journal 10 (4):244-8.

Farmer, David. 1997. "Purchasing myopia — revisited." European journal of purchasing \& supply management 3 (1):1-8.

Feng, Yunting, Qinghua Zhu, and Kee-Hung Lai. 2017. "Corporate social responsibility for supply chain management: A literature review and bibliometric analysis." Journal of cleaner production 158:296-307.

Field, Joy M, and Larry C Meile. 2008. "Supplier relations and supply chain performance in financial services processes." International Journal of Operations \& Production Management 28 (2):185-206.

Finne, Max, and Jan Holmström. 2013. "A manufacturer moving upstream: triadic collaboration for service delivery." Supply Chain Management: An International Journal 18 (1):21-33.

Fischl, Maria, Maike Scherrer-Rathje, and Thomas Friedli. 2014. "Digging deeper into supply risk: a systematic literature review on price risks." Supply Chain Management: An International Journal 19 (5/6):480-503.

Fisher, Marshall L. 1997. "What is the right supply chain for your product." Harvard business review 75:105-16.

Flick, Uwe. 2008. Managing quality in qualitative research: Sage.

Ford, David. 1990. Understanding business markets: Interaction, relationships and networks: Academic Pr.

Forrester, J W. 1961. Industrial Dynamics. Wiley, New York: M.I.T. Press, Cambridge, Mass.

Fredendall, Lawrence D., Peter Letmathe, and Nadine Uebe-Emden. 2016. "Supply chain management practices and intellectual property protection in China: Perceptions of Mittelstand managers." International Journal of Operations \& Production Management 36 (2):135-63. doi: doi:10.1108/IJOPM-12-2013-0526.

$\mathrm{Fu}, \mathrm{Na}$, Patrick C Flood, Janine Bosak, Tim Morris, and Philip O'Regan. 2013. "Exploring the performance effect of HPWS on professional service supply chain management." Supply Chain Management: An International Journal 18 (3):292-307.

Genovese, Andrea, SC Lenny Koh, and Adolf Acquaye. 2013. "Energy efficiency retrofitting services supply chains: Evidence about stakeholders and configurations from the Yorskhire and Humber region case." International Journal of Production Economics 144 (1):20-43.

Giannakis, Mihalis. 2011a. "Conceptualizing and managing service supply chains." The Service Industries Journal 31 (11):1809-23.

2011b. "Management of service supply chains with a service-oriented reference model: the case of management consulting." Supply Chain Management: An International Journal 16 (5):346-61.

Gliatis, Vassilis A, and Ioannis E Minis. 2007. "Service attribute-process matrix: A tool for designing and managing services." Journal of Systems Science and Systems Engineering 16 (3):257-76.

Guajardo, Jose A, Morris A \%J Manufacturing Cohen, and Service Operations Management. 2018. "Service Differentiation and Operating Segments: A Framework and an Application to After-Sales Services."

Guardian, The. 2015. "Service sector boom puts US economy on track for strong second half of 2014." In The Guardian. UK.

Habib, F., M. Bastl, and C. Pilbeam. 2015. "Strategic responses to power dominance in buyer-supplier relationships: A weaker actor's perspective." International Journal of Physical Distribution \& Logistics Management 45 (1/2):182-203. doi: doi:10.1108/IJPDLM-05-2013-0138.

Handfield, Robert B, and Ernst L Nichols. 1999. "Introduction to supply chain management." Univerza na Primorskem, Znanstveno-raziskovalno središče.

Harland, Christine M., Richard C. Lamming, and Paul D. Cousins. 1999. "Developing the concept of supply strategy." International Journal of Operations \& Production Management 19 (7):650-74. doi: doi:10.1108/01443579910278910.

Harvey, Jean. 2016. "Professional service supply chains." Journal of Operations Management 42:52-61. doi: http://dx.doi.org/10.1016/j.jom.2016.03.002.

Haszlinna Mustaffa, Noorfa, and Andrew Potter. 2009. "Healthcare supply chain management in Malaysia: a case study." Supply Chain Management: An International Journal 14 (3):234-43.

He, Meiling, Junping Xie, Xiaohui Wu, Qifan Hu, and Yu Dai. 2016. "Capability Coordination in Automobile Logistics Service Supply Chain Based on Reliability." Procedia Engineering 137:325-33. doi: http://dx.doi.org/10.1016/j.proeng.2016.01.265.

He, Yuanqiong, and Kin Keung Lai. 2012. "Supply chain integration and service oriented transformation: Evidence from Chinese equipment manufacturers." International Journal of Production Economics 135 (2):791-9.

Heydari, Jafar, Tsan-Ming Choi, and Saghi Radkhah. 2017. "Pareto improving supply chain coordination under a money-back guarantee service program." Service Science 9 (2):91-105.

Hines, Peter. 1994. Creating world class suppliers: Unlocking mutual competitive advantage: Pitman Pub.

Holmström, Jan, Saara Brax, and Timo Ala-Risku. 2010. "Comparing provider-customer constellations of visibilitybased service." Journal of Service Management 21 (5):675-92. 
Holmström, Jan, and Jouni Partanen. 2014. "Digital manufacturing-driven transformations of service supply chains for complex products." Supply Chain Management: An International Journal 19 (4):421-30.

Houlihan, John B. 1988. "International supply chains: a new approach." Management Decision 26 (3):13-9.

Hu, Benyong, and Yi Feng. 2017. "Optimization and coordination of supply chain with revenue sharing contracts and service requirement under supply and demand uncertainty." International Journal of Production Economics 183:185-93.

Hugos, Michael H. 2003. Essentials of Supply Chain Management, Essentials Series. Hoboken, N.J.: Wiley.

Hussain, Matloub, Mehmood Khan, and Raid Al-Aomar. 2016. "A framework for supply chain sustainability in service industry with Confirmatory Factor Analysis." Renewable and Sustainable Energy Reviews 55:130112. doi: http://dx.doi.org/10.1016/j.rser.2015.07.097.

Jarillo, J Carlos. 1993. Strategic networks: creating the borderless organization: Oxford : Butterworth-Heinemann

Jie, Ferry, and Denise Gengatharen. "Australian food retail supply chain analysis." 0 (0):null. doi: doi:10.1108/BPMJ-03-2017-0065.

Jin, Zhen, and Xuejing Yang. 2016. "The Research on International Supply Chain Management." Management \& Engineering (25):101. doi: http://dx.doi.org.ezproxy.uws.edu.au/10.5503/J.ME.2016.25.011.

Johnsen, Thomas E., Joe Miemczyk, and Mickey Howard. 2017. "A systematic literature review of sustainable purchasing and supply research: Theoretical perspectives and opportunities for IMP-based research." Industrial Marketing Management 61:130-43. doi: http://dx.doi.org/10.1016/j.indmarman.2016.03.003.

Jones, Thomas C., and Daniel W. Riley. "Using Inventory for Competitive Advantage through." Supply Chain Management:16-26.

Kathawala, Yunus, and Khaled Abdou. 2003. "Supply chain evaluation in the service industry: a framework development compared to manufacturing." Managerial Auditing Journal 18 (2):140-9.

Keller, Scott B, Daniel F Lynch, Alexander E Ellinger, John Ozment, and Roger Calantone. 2006. "The impact of internal marketing efforts in distribution service operations." Journal of Business logistics 27 (1):109-37.

Kowalkowski, Christian, Charlotta Windahl, Daniel Kindström, and Heiko Gebauer. 2015. "What service transition? Rethinking established assumptions about manufacturers' service-led growth strategies." Industrial Marketing Management 45:59-69.

Kuo, Tsai Chi, and Miao Ling Wang. 2012. "The optimisation of maintenance service levels to support the product service system." International Journal of Production Research 50 (23):6691-708.

Kurata, Hisashi, and Seong-Hyun Nam. 2010. "After-sales service competition in a supply chain: Optimization of customer satisfaction level or profit or both?" International Journal of Production Economics 127 (1):136-46. 2013. "After-sales service competition in a supply chain: Does uncertainty affect the conflict between profit maximization and customer satisfaction?" International Journal of Production Economics 144 (1):268-80.

La Londe, Bernard J. 1997. "Supply chain management: myth or reality?" Supply Chain Management Review 1 (1):67.

Lamming, Richard. 1993. Beyond partnership: strategies for innovation and lean supply: Prentice Hall.

Lay, Gunter, Giacomo Copani, Angela Jäger, and Sabine Biege. 2010. "The relevance of service in European manufacturing industries." Journal of Service Management 21 (5):715-26.

Leksono, Eko Budi, Suparno Suparno, and Iwan Vanany. 2019. "Integration of a Balanced Scorecard, DEMATEL, and ANP for Measuring the Performance of a Sustainable Healthcare Supply Chain." Sustainability 11 (13):3626.

Li, Li, Li Jiang, and Liming Liu. 2012. "Service and price competition when customers are naive." Production Operations Management 21 (4):747-60.

Li, Ling, John B Ford, Xin Zhai, and Li Xu. 2012. "Relational benefits and manufacturer satisfaction: An empirical study of logistics service in supply chain." International Journal of Production Research 50 (19):5445-59.

Li, Xiang 2014. "Operations management of logistics and supply chain: Issues and directions." Discrete Dynamics in Nature Society 2014.

Li, Xiang \%J Discrete Dynamics in Nature, and Society. 2014. "Operations management of logistics and supply chain: Issues and directions." 2014.

Li, Xiang, Yongjian Li, Xiaoqiang Cai, and Jun Shan. 2016. "Service channel choice for supply chain: Who is better off by undertaking the service?" Production Operations Management 25 (3):516-34.

Li, Yongjian, Xiukun Zhao, Dan Shi, and Xiang Li. 2014. "Governance of sustainable supply chains in the fast fashion industry." European Management Journal 32 (5):823-36.

Liao, Shu-Hsien, Da-Chian Hu, and Li-Wen Ding. 2017. "Assessing the influence of supply chain collaboration value innovation, supply chain capability and competitive advantage in Taiwan's networking communication industry." International Journal of Production Economics 191:143-53. doi: http://dx.doi.org/10.1016/j.ijpe.2017.06.001. 
Lillrank, Paul, Johan Groop, and Julia Venesmaa. 2011. "Processes, episodes and events in health service supply chains." Supply Chain Management: An International Journal 16 (3):194-201.

Liu, Wei-hua, Dong Xie, and Xue-cai Xu. 2013. "Quality supervision and coordination of logistic service supply chain under multi-period conditions." International Journal of Production Economics 142 (2):353-61.

Liu, Weihua, Enze Bai, Liwei Liu, and Wanying Wei. 2017. "A Framework of Sustainable Service Supply Chain Management: A Literature Review and Research Agenda." Sustainability 9 (3). doi: http://dx.doi.org.ezproxy.uws.edu.au/10.3390/su9030421.

Liu, Weihua, Meiying Ge, Wenchen Xie, Yi Yang, and Haitao Xu. 2014. "An order allocation model in logistics service supply chain based on the pre-estimate behaviour and competitive-bidding strategy." International Journal of Production Research 52 (8):2327-44. doi: 10.1080/00207543.2013.857059.

Liu, Weihua, Chunling Liu, Xuecai Xu, and Xing Bao. 2014. "An order allocation model in multi-period logistics service supply chain based on cumulative prospect theory and capacity matching constraint." International Journal of Production Research 52 (22):6608-26. doi: 10.1080/00207543.2014.904968.

Liu, Weihua, and Yijia Wang. 2015. "Quality control game model in logistics service supply chain based on different combinations of risk attitude." International Journal of Production Economics 161:181-91.

Liu, Weihua, Dong Xie, Yang Liu, and Xiaoyan Liu. 2015. "Service capability procurement decision in logistics service supply chain: a research under demand updating and quality guarantee." International Journal of Production Research 53 (2):488-510. doi: 10.1080/00207543.2014.955219.

Liu, Weihua, Yi Yang, Xiang Li, Haitao Xu, and Dong Xie. 2012. "A time scheduling model of logistics service supply chain with mass customized logistics service." Discrete Dynamics in Nature Society 2012.

Liu, Weihua, Xuan Zhao, Ou Tang, and Haitao Xu. 2017a. "Impacts of demand and supply factors on the capacity scheduling performance of logistics service supply chain with mass customisation service modes: an empirical study from China." Production Planning \& Control 28 (9):727-43.

2017b. "Impacts of demand and supply factors on the capacity scheduling performance of logistics service supply chain with mass customisation service modes: an empirical study from China." Production Planning \& Control $28(9): 1-17$.

Liu, WH, and D Xie. 2013. "Quality decision of the logistics service supply chain with service quality guarantee." International Journal of Production Research 51 (5):1618-34.

Löfberg, Nina, Lars Witell, and Anders Gustafsson. 2010. "Service strategies in a supply chain." Journal of Service Management 21 (4):427-40.

Lovelock, Christopher H. 1983. "Classifying services to gain strategic marketing insights." the Journal of Marketing:9-20.

Maloni, Michael, Stacy M Campbell, David Gligor, Christina R Scherrer, and Elizabeth Boyd. 2017. "Exploring the effects of workforce level on supply chain job satisfaction and industry commitment." International Journal of Logistics Management, The (just-accepted):00-.

Mandal, Santanu, and Rajneesh Ranjan Jha. 2017. "Exploring the importance of collaborative assets to hospitalsupplier integration in healthcare supply chains." International Journal of Production Research:1-18. doi: http://dx.doi.org/10.1080/00207543.2017.1381349

Martin, Judith, Judith Martin, Erik Hofmann, and Erik Hofmann. 2017. "Involving financial service providers in supply chain finance practices: Company needs and service requirements." Journal of Applied Accounting Research 18 (1):42-62.

Masali, Anupama Devendrakumar. 2016. "Intra-Industry Trade in Manufacturing Supply Chain: An Empirical Assessment of the India-ASEAN Case." International Journal of Supply Chain Management 5 (2):27-35.

Masteika, Ignas, and Jonas Čepinskis. 2015. "Dynamic Capabilities in Supply Chain Management." Procedia - Social and Behavioral Sciences 213:830-5. doi: http://dx.doi.org/10.1016/j.sbspro.2015.11.485.

Meijboom, Bert, Saskia Schmidt-Bakx, and Gert Westert. 2011. "Supply chain management practices for improving patient-oriented care." Supply Chain Management: An International Journal 16 (3):166-75.

Melo, M Teresa, Stefan Nickel, and Francisco Saldanha-Da-Gama. 2009. "Facility location and supply chain management-A review." European journal of operational research 196 (2):401-12.

Mentzer, John T, William DeWitt, James S Keebler, Soonhong Min, Nancy W Nix, Carlo D Smith, and Zach G Zacharia. 2001. "Defining supply chain management." Journal of Business logistics 22 (2):1-25.

Murali, S, S Pugazhendhi, C \%J Journal of Retailing Muralidharan, and Consumer Services. 2016. "Modelling and investigating the relationship of after sales service quality with customer satisfaction, retention and loyalty-a case study of home appliances business." 30:67-83.

Narus, James A., and James C. Anderson. 1995. "Using Teams to Manage Collaborative Relationships in Business Markets." Journal of Business-to-Business Marketing 2 (3):17-46. doi: 10.1300/J033v02n03_02. 
Nematollahi, Mohammadreza, Seyyed-Mahdi Hosseini-Motlagh, and Jafar Heydari. 2017. "Economic and social collaborative decision-making on visit interval and service level in a two-echelon pharmaceutical supply chain." Journal of cleaner production 142:3956-69.

Newbert, Scott L. 2007. "Empirical research on the resource-based view of the firm: an assessment and suggestions for future research." Strategic management journal 28 (2):121-46. doi: 10.1002/smj.573.

Nie, Winter, and Deborah L Kellogg. 1999. "How professors of operations management view service operations?" Production and Operations management 8 (3):339-55.

Oliver, R Keith, and Michael D Webber. 1982. "Supply-chain management: logistics catches up with strategy." Outlook 5 (1):42-7.

Piplani, Rajesh, and Ashish Saraswat. 2012. "Robust optimisation approach to the design of service networks for reverse logistics." International Journal of Production Research 50 (5):1424-37.

Popescu, Corina, M Cavia Soto, and Jose L Martinez Lastra. 2012. "A Petri net-based approach to incremental modelling of flow and resources in service-oriented manufacturing systems." International Journal of Production Research 50 (2):325-43.

Porter, Michael E. 1987. "From competitive advantage to corporate strategy." 65 (3):43.

Puspitasari, Ira, and Ferry Jie. 2018. "Making the Information Technology (IT) business alignment works: a framework of IT-based competitive strategy."

Qin, Xinghong, Qiang Su, and Samuel H Huang. 2017. "Extended warranty strategies for online shopping supply chain with competing suppliers considering component reliability." Journal of Systems Science and Systems Engineering:1-21. doi: https://doi.org/10.1007/s11518-017-5355-3

Qin, Xinghong, Qiang Su, Samuel H Huang, Uco Jillert Wiersma, and Ming Liu. 2017. "Service quality coordination contracts for online shopping service supply chain with competing service providers: integrating fairness and individual rationality." Operational Research:1-28. doi: https://doi.org/10.1007/s12351-016-0288-z. 2019. "Service quality coordination contracts for online shopping service supply chain with competing service providers: integrating fairness and individual rationality." Operational Research 19 (1):269-96.

Rabinovich, Elliot. 2007. "Linking e-service quality and markups: The role of imperfect information in the supply chain." Journal of Operations Management 25 (1):14-41.

Rahimnia, Fariborz, and Mahdi Moghadasian. 2010. "Supply chain leagility in professional services: how to apply decoupling point concept in healthcare delivery system." Supply Chain Management: An International Journal 15 (1):80-91.

Reimann, Felix, and David J. Ketchen. 2017. "Power in Supply Chain Management." Journal of Supply Chain Management 53 (2):3-9. doi: 10.1111/jscm.12140.

Rezapour, Shabnam, Janet K. Allen, and Farrokh Mistree. 2016. "Reliable product-service supply chains for repairable products." Transportation Research Part E: Logistics and Transportation Review 95:299-321. doi: http://dx.doi.org/10.1016/j.tre.2016.07.016.

Robinson, Carol J, and Manoj K Malhotra. 2005. "Defining the concept of supply chain quality management and its relevance to academic and industrial practice." International Journal of Production Economics 96 (3):315-37.

Roh, Joseph, Virpi Turkulainen, Judith M Whipple, and Morgan Swink. 2017. "Organizational design change in multinational supply chain organizations." International Journal of Logistics Management, The (justaccepted):00-.

Ross, Anthony, Vaidyanathan Jayaraman, and Powell Robinson. 2007. "Optimizing 3PL service delivery using a costto-serve and action research framework." International Journal of Production Research 45 (1):83-101.

Rossi, Silvia, Claudia Colicchia, Alessandra Cozzolino, and Martin Christopher. 2013. "The logistics service providers in eco-efficiency innovation: an empirical study." Supply Chain Management: An International Journal 18 (6):583-603.

Roth, Aleda V, and Larry J Menor. 2003. "Insights into Service Operatios Management: A Research Agenda." Production and Operations management 12:145-64.

Rowley, Jennifer, and Frances Slack. 2004. "Conducting a literature review." Management Research News 27 (6):319. doi: doi:10.1108/01409170410784185.

Ru, Peng, Qiang Zhi, Fang Zhang, Xiaotian Zhong, Jianqiang Li, and Jun Su. 2012. "Behind the development of technology: The transition of innovation modes in China's wind turbine manufacturing industry." Energy Policy 43:58-69.

Saban, Kenneth, John R. Mawhinney, and Matthew J. Drake. 2017. "An integrated approach to managing extended supply chain networks." Business Horizons 60 (5):689-97. doi: http://dx.doi.org/10.1016/j.bushor.2017.05.012.

Saccani, Nicola, Pontus Johansson, and Marco Perona. 2007. "Configuring the after-sales service supply chain: A multiple case study." International Journal of Production Economics 110 (1):52-69. 
Saha, Anup Kumar, Bipasha Saha, Tonmoy Choudhury, and Ferry Jie. 2019. "Quality versus volume of carbon disclosures and carbon reduction targets: Evidence from UK higher education institutions." Pacific Accounting Review.

Sajjad, Aymen, Gabriel Eweje, and David Tappin. 2015. "Sustainable Supply Chain Management: Motivators and Barriers." Business Strategy and the Environment 24 (7):643-55. doi: 10.1002/bse.1898.

Sampson, Scott E. 2000. "Customer-supplier duality and bidirectional supply chains in service organizations." International Journal of Service Industry Management 11 (4):348-64.

Sampson, Scott E, and Craig M Froehle. 2006. "Foundations and implications of a proposed unified services theory." Production and Operations management 15 (2):329-43.

Schaltegger, Stefan, and Roger Burritt. 2014. "Measuring and managing sustainability performance of supply chains: Review and sustainability supply chain management framework." Supply Chain Management: An International Journal 19 (3):232-41. doi: doi:10.1108/SCM-02-2014-0061.

Scheibe, Kevin P, and Jennifer Blackhurst. 2017. "Supply chain disruption propagation: a systemic risk and normal accident theory perspective." International Journal of Production Research:1-17.

Selviaridis, Kostas, and Andreas Norrman. 2014. "Performance-based contracting in service supply chains: a service provider risk perspective." Supply Chain Management: An International Journal 19 (2):153-72.

Sengupta, Kaushik, Daniel R Heiser, and Lori S Cook. 2006. "Manufacturing and service supply chain performance: a comparative analysis." Journal of Supply Chain Management 42 (4):4-15.

Seuring, Stefan, and Stefan Gold. 2012. "Conducting content-analysis based literature reviews in supply chain management." Supply Chain Management: An International Journal 17 (5):544-55. doi: doi:10.1108/13598541211258609.

Seuring, Stefan, and Martin Müller. 2008. "From a literature review to a conceptual framework for sustainable supply chain management." Journal of cleaner production 16 (15):1699-710.

Shapiro, Jeremy F. 2001. Modeling the Supply Chain: Pacific Grove, CA : Duxbury/Thomson Learning.

Sieke, Marcel A, Ralf W Seifert, and Ulrich W Thonemann. 2012. "Designing service level contracts for supply chain coordination." Production and Operations management 21 (4):698-714.

Sigala, Marianna. 2014. "Customer Involvement in Sustainable Supply Chain Management." Cornell Hospitality Quarterly 55 (1):76-88. doi: 10.1177/1938965513504030.

Snehota, Ivan, and Hakan Hakansson. 1995. Developing relationships in business networks: Routledge London.

Snow, Charles C., Raymond E. Miles, and Henry J. Coleman. 1992. "Managing 21st century network organizations." Organizational Dynamics 20 (3):5-20. doi: http://dx.doi.org/10.1016/0090-2616(92)90021-E.

Spohrer, Jim, Paul P. Maglio, John Bailey, and Daniel Gruhl. 2007. "Steps Toward a Science of Service Systems." Computer 40 (1):71-7. doi: 10.1109/mc.2007.33.

Stank, Theodore, Chad Autry, Patricia Daugherty, and David Closs. 2015. "Reimagining the 10 Megatrends That Will Revolutionize Supply Chain Logistics." Transportation Journal 54 (1):7-32. doi: 10.5325/transportationj.54.1.0007.

Stephens, Victoria Louise, Gareth RT White, and Rachel Mason-Jones. 2016. "Problematising the concept of'sustainability "in the supply chain through systematic literature review."

Stevens, Graham C. 1989. "Integrating the supply chain." International Journal of Physical Distribution \& Materials Management 19 (8):3-8.

Stuart, F Ian. 1997. "Supply-chain strategy: organizational influence through supplier alliances." British Journal of management 8 (3):223-36.

Sun, Miao, Ye Tian, Yufei Yan, and Yi \%J Nankai Business Review International Liao. 2018. "Improving the profit by using a mixed after-sales service as a market segmentation."

Sutrisna, Monty, Mohan M Kumaraswamy, Moumita Das, Jack CP Cheng, and Kincho H Law. 2015. "An ontologybased web service framework for construction supply chain collaboration and management." Engineering, Construction and Architectural Management.

Thai, Vinh, Ferry \%J Asia Pacific Journal of Marketing Jie, and Logistics. 2018. "The impact of total quality management and supply chain integration on firm performance of container shipping companies in Singapore." (just-accepted):00-.

Thorelli, Hans B. 1986. "Networks: Between markets and hierarchies." Strategic management journal 7 (1):37-51. doi: 10.1002/smj.4250070105.

Torraco, Richard J. 2005. "Writing Integrative Literature Reviews: Guidelines and Examples." Human Resource Development Review 4 (3):356-67. doi: 10.1177/1534484305278283.

Touboulic, Anne, and Helen Walker. 2016. "A relational, transformative and engaged approach to sustainable supply chain management: The potential of action research." Human Relations 69 (2):301-43. doi: $10.1177 / 0018726715583364$. 
Tranfield, David, David Denyer, and Palminder Smart. 2003. "Towards a Methodology for Developing EvidenceInformed Management Knowledge by Means of Systematic Review." British Journal of management 14 (3):207-22. doi: 10.1111/1467-8551.00375.

Tseng, Ming-Lang, Ming K Lim, Wai-Peng Wong, Yi-Chun Chen, and Yuanzhu Zhan. 2018. "A framework for evaluating the performance of sustainable service supply chain management under uncertainty." International Journal of Production Economics 195:359-72.

Tseng, Ming-Lang, Ming K. Lim, Wai-Peng Wong, Yi-Chun Chen, and Yuanzhu Zhan. 2016. "A framework for evaluating the performance of sustainable service supply chain management under uncertainty." International Journal of Production Economics. doi: http://dx.doi.org/10.1016/j.ijpe.2016.09.002.

van der Valk, Wendy, and Finn Wynstra. 2014. "Variety in business-to-business services and buyer-supplier interaction: The case of cleaning services." International Journal of Operations \& Production Management 34 (2):195-220.

Vandaele, Darline, and Paul Gemmel. 2007. "Purchased business services influence downstream supply chain members." International Journal of Service Industry Management 18 (3):307-21.

Venkatesh, Viswanath. 2013. "IT, Supply Chain, and Services: Looking Ahead." Journal of Operations Management $6(31): 281-4$.

Véronneau, Simon, and Jacques Roy. 2009. "RFID benefits, costs, and possibilities: The economical analysis of RFID deployment in a cruise corporation global service supply chain." International Journal of Production Economics 122 (2):692-702.

Vickery, Shawnee K, Jayanth Jayaram, Cornelia Droge, and Roger Calantone. 2003. "The effects of an integrative supply chain strategy on customer service and financial performance: an analysis of direct versus indirect relationships." Journal of Operations Management 21 (5):523-39.

Vom Brocke, Jan, Alexander Simons, Bjoern Niehaves, Kai Riemer, Ralf Plattfaut, and Anne Cleven. 2009. Reconstructing the giant: On the importance of rigour in documenting the literature search process. Paper presented at the ECIS.

Wang, Lisha, Huaming Song, and Yongzhao Wang. 2017. "Pricing and service decisions of complementary products in a dual-channel supply chain." Computers \& Industrial Engineering 105:223-33.

Wang, Yulan, Stein W Wallace, Bin Shen, and Tsan-Ming Choi. 2015. "Service supply chain management: A review of operational models." European Journal of Operational Research 247 (3):685-98.

Webster, Jane, and Richard T Watson. 2002. "Analyzing the past to prepare for the future: Writing a literature review." MIS quarterly 26 (2):xiii-xxiii.

Wei-hua, Liu, Xu Xue-cai, Ren Zheng-xu, and Peng Yan. 2011. "An emergency order allocation model based on multi-provider in two-echelon logistics service supply chain." Supply Chain Management: An International Journal 16 (6):391-400.

Wei, Yihua, Qiying Hu, and Chen Xu. 2013. "Ordering, pricing and allocation in a service supply chain." International Journal of Production Economics 144 (2):590-8.

Winter, Marc, and A. Michael Knemeyer. 2013. "Exploring the integration of sustainability and supply chain management: Current state and opportunities for future inquiry." International Journal of Physical Distribution \& Logistics Management 43 (1):18-38. doi: doi:10.1108/09600031311293237.

Womack, J.P. , D.T. Jones, and D Roos. 1990. The Machine that Changed the World. New York, NY: Macmillan.

World Bank. 2016. "World Development Indicators." In.: World Bank.

Wren, Anthony, Sarah Fores, Ann Kwan, Raymond Kwan, Margaret Parker, and Les Proll. 2003. "A flexible system for scheduling drivers." Journal of scheduling 6 (5):437-55.

Yang, Miying, Palie Smart, Mukesh Kumar, Mark Jolly, and Steve Evans. 2018. "Product-service systems business models for circular supply chains." Production Planning \& Control 29 (6):498-508.

Yawar, Sadaat Ali, and Stefan Seuring. 2017. "Management of social issues in supply chains: a literature review exploring social issues, actions and performance outcomes." Journal of Business Ethics 141 (3):621.

Youngdahl, William E, and Arvinder PS Loomba. 2000. "Service-driven global supply chains." International Journal of Service Industry Management 11 (4):329-47.

Youngdahl, William, Kannan Ramaswamy, and Rohit Verma. 2008. Exploring new research frontiers in offshoring knowledge and service processes: Elsevier.

Yu, Yunlong, and Tiaojun Xiao. 2017. "Pricing and cold-chain service level decisions in a fresh agri-products supply chain with logistics outsourcing." Computers \& Industrial Engineering 111:56-66.

Yuen, Kum Fai, and Vinh Van Thai. 2017. "The influence of supply chain integration on operational performance: A comparison between product and service supply chains." The International Journal of Logistics Management 28 (2):444-63. 
Yuen, Kum Fai, Kum Fai Yuen, Vinh Van Thai, and Vinh Van Thai. 2017. "The influence of supply chain integration on operational performance: A comparison between product and service supply chains." The International Journal of Logistics Management 28 (2):444-63.

Zhang, Jie J., Nitin Joglekar, and Rohit Verma. 2014. "Signaling eco-certification: Implications for service coproduction and resource efficiency." Journal of Service Management 25 (4):494-511.

Zhang, Shuai, Song Xu, Wenyu Zhang, Dejian Yu, and Kai Chen. 2017. "A hybrid approach combining an extended BBO algorithm with an intuitionistic fuzzy entropy weight method for QoS-aware manufacturing service supply chain optimization." Neurocomputing 272.

Zhong, Ray Y, Stephen T Newman, George Q Huang, and Shulin Lan. 2016. "Big Data for supply chain management in the service and manufacturing sectors: Challenges, opportunities, and future perspectives." Computers \& Industrial Engineering 101:572-91.

Zhou, Guodong, and Ganlin Ye. 1988. "Forward-backward search method." Journal of Computer Science and Technology 3 (4):289-305.

Zhu, Qinghua, and Yihui Tian. 2016. "Developing a remanufacturing supply chain management system: a case of a successful truck engine remanufacturer in China." Production Planning \& Control 27 (9):708-16. doi: 10.1080/09537287.2016.1166282.

Zorn, Ted, and Nittaya Campbell. 2006. "Improving The Writing Of Literature Reviews Through A Literature Integration Exercise." Business Communication Quarterly 69 (2):172-83. doi: 10.1177/1080569906287960.

Zsidisin, George A, Minjoon Jun, and Laural L Adams. 2000. "The relationship between information technology and service quality in the dual-direction supply chain: A case study approach." International Journal of Service Industry Management 11 (4):312-28.

$\mathrm{Zu}$, Xingxing, and Hale Kaynak. 2012. "An agency theory perspective on supply chain quality management." International Journal of Operations \& Production Management 32 (4):423-46. 